Western University

Scholarship@Western

Obstetrics \& Gynaecology Publications

Obstetrics \& Gynaecology Department

9-1-2013

\title{
Stress-inducible phosphoprotein 1 has unique cochaperone activity during development and regulates cellular response to ischemia via the prion protein.
}

Flavio H Beraldo

Iaci N Soares

Daniela F Goncalves

Jue Fan

Anu A Thomas

See next page for additional authors

Follow this and additional works at: https://ir.lib.uwo.ca/obsgynpub

Part of the Obstetrics and Gynecology Commons

Citation of this paper:

Beraldo, Flavio H; Soares, Iaci N; Goncalves, Daniela F; Fan, Jue; Thomas, Anu A; Santos, Tiago G; Mohammad, Amro H; Roffé, Martin; Calder, Michele D; Nikolova, Simona; Hajj, Glaucia N; Guimaraes, Andre L; Massensini, Andre R; Welch, Ian; Betts, Dean H; Gros, Robert; Drangova, Maria; Watson, Andrew J; Bartha, Robert; Prado, Vania F; Martins, Vilma R; and Prado, Marco A M, "Stressinducible phosphoprotein 1 has unique cochaperone activity during development and regulates cellular response to ischemia via the prion protein." (2013). Obstetrics \& Gynaecology Publications. 22.

https://ir.lib.uwo.ca/obsgynpub/22 


\section{Authors}

Flavio H Beraldo, Iaci N Soares, Daniela F Goncalves, Jue Fan, Anu A Thomas, Tiago G Santos, Amro H Mohammad, Martin Roffé, Michele D Calder, Simona Nikolova, Glaucia N Hajj, Andre L Guimaraes, Andre R Massensini, Ian Welch, Dean H Betts, Robert Gros, Maria Drangova, Andrew J Watson, Robert Bartha, Vania F Prado, Vilma R Martins, and Marco A M Prado 


\title{
Stress-inducible phosphoprotein 1 has unique cochaperone activity during development and regulates cellular response to ischemia via the prion protein
}

\author{
Flavio H. Beraldo, ${ }^{* \dagger}$, Iaci N. Soares, ${ }^{*,+}, \#$ Daniela F. Goncalves, ${ }^{*}, * *$ Jue Fan, ${ }^{*}$ \\ Anu A. Thomas, ${ }^{*}{ }^{\dagger}$ Tiago G. Santos, ${ }^{\dagger \dagger}$ Amro H. Mohammad, ${ }^{*+}$ Martin Roffé, ${ }^{\dagger \dagger}$ \\ Michele D. Calder, ${ }^{\dagger, \S,++}$ Simona Nikolova,* Glaucia N. Hajj, ${ }^{\dagger+}$ Andre L. Guimaraes, ${ }^{*}, \S \S$ \\ Andre R. Massensini, ${ }^{* *}$ Ian Welch,,$\|$ Dean H. Betts, ${ }^{\dagger,+\ddagger}$ Robert Gros, ${ }^{*}, \dagger$ \\ Maria Drangova, $*$, I Andrew J. Watson, ${ }^{\dagger,}$, , $+\neq$ Robert Bartha, ${ }^{+, \text {I }}$ Vania F. Prado, $*,+,+, 1$ \\ Vilma R. Martins, ${ }^{\dagger+1,2}$ and Marco A. M. Prado*,+,+,1,2 \\ * Robarts Research Institute, ${ }^{\dagger}$ Department of Physiology and Pharmacology, ${ }^{\ddagger}$ Department of Anatomy \\ and Cell Biology, ${ }^{\S}$ Department of Obstetrics and Gynaecology, $\|_{\text {Animal Care and Veterinarian }}$ \\ Services, and ${ }^{9}$ Department of Medical Biophysics, University of Western Ontario, London, Ontario, \\ Canada; "Program in Molecular Medicine and **Department of Physiology and Biophysics, Federal \\ University of Minas Gerais, Belo Horizonte, Minas Gerais, Brazil; ${ }^{\dagger \dagger}$ Department of Molecular and \\ Cell Biology, International Research Center, A. C. Camargo Cancer Center and National Institute for \\ Translational Neuroscience, São Paulo, Brazil; ${ }^{\ddagger \ddagger}$ Children’s Health Research Institute-Lawson Health \\ Research Institute, London, Ontario, Canada; and ${ }^{\$ \S}$ University of Montes Claros, Montes Claros, \\ Minas Gerais, Brazil
}

ABSTRACT Stress-inducible phosphoprotein 1 (STI1) is part of the chaperone machinery, but it also functions as an extracellular ligand for the prion protein. However, the physiological relevance of these STI1 activities in vivo is unknown. Here, we show that in the absence of embryonic STI1, several Hsp90 client proteins are decreased by $50 \%$, although $\mathrm{Hsp} 90$ levels are unaffected. Mutant STI1 mice showed increased caspase-3 activation and $50 \%$ impairment in cellular proliferation. Moreover, placental disruption and lack of cellular viability were linked to embryonic death by E10.5 in STI1-mutant mice. Rescue of embryonic lethality in these mutants, by transgenic expression of the STI1 gene, supported a unique role for STI1 during embryonic development. The response of STI1 haploinsufficient mice to cellular stress seemed compromised, and mutant mice showed increased vulnerability to ischemic insult. At the cellular level, ischemia increased the secretion of STI1 from wild-type astrocytes by 3-fold,

Abbreviations: BAC, bacterial artificial chromosome; CM, conditioned medium; DIV, days in vitro; GRK2, G-proteincoupled receptor kinase 2; H\&E, hematoxylin and eosin; HOP, heat-shock organizing protein; Hsp70, heat-shock protein 70; Hsp90, heat-shock protein 90; MCAO, middle cerebral artery occlusion; MEF, mouse embryonic fibroblast; micro-CT, microcomputed tomography; MRI, magnetic resonance imaging; OGD, oxygen and glucose deprivation; p53, protein 53; Piwi, P-element-induced wimpy testis; $\mathrm{PrP}^{\mathrm{C}}$, prion protein; STAT3, signal transducer and activator of transcription 3; STI1, stressinducible phosphoprotein I; Stip1, mouse stress-inducible phosphoprotein I; TPR, tetratricopeptide repeat whereas STI1 haploinsufficient mice secreted half as much STI1. Interesting, extracellular STI1 prevented ischemia-mediated neuronal death in a prion proteindependent way. Our study reveals essential roles for intracellular and extracellular STI1 in cellular resilience.-Beraldo, F. H., Soares, I. N., Goncalves, D. F., Fan, J., Thomas, A. A., Santos, T. G., Mohammad, A. H., Roffe, M., Calder, M. D., Nikolova, S., Hajj, G. N., Guimaraes, A. N., Massensini, A. R., Welch, I., Betts, D. H., Gros, R., Drangova, M., Watson, A. J., Bartha, R., Prado, V. F., Martins, V. R., and Prado, M. A. M. Stress-inducible phosphoprotein 1 has unique cochaperone activity during development and regulates cellular response to ischemia via the prion protein. FASEB J. 27, 000-000 (2013). www.fasebj.org

Key Words: Hsp90 $\cdot$ stroke $\cdot$ maternal-effect gene $\cdot H s p 70 \cdot$ prion protein

THE CHAPERONES HEAT-SHOCK PROTEIN 90 and 70 (Hsp90 and Hsp70) cooperate to assist the folding and

\footnotetext{
${ }^{1}$ These authors contributed equally to this work.

${ }^{2}$ Correspondence: M.A.M.P., Robarts Research Institute, P.O. Box 5015, 100 Perth Dr. London, ON, Canada, N6A 5K8. E-mail: mprado@robarts.ca; V.R.M., A. C. Camargo Cancer Center, Rua Taguá, 440-CEP: 01508-010, Liberdade-São Paulo, SP, Brazil. E-mail: vmartins@cipe.accamargo.org.br doi: 10.1096/fj.13-232280

This article includes supplemental data. Please visit $h t t p: / /$ www.fasebj.org to obtain this information.
} 
stability of many client proteins that are critical for cellular homeostasis $(1,2)$. Cochaperones are thought to play important roles in assisting Hsp70 and Hsp90 (3). The cochaperone stress-inducible phosphoprotein 1 [STI1; or heat-shock organizing protein (Hop)] is thought to participate in different aspects of cellular function (4). The protein contains 3 tetratricopeptide repeat (TPR)-containing domains (TPR1, TPR2A, and TPR2B), which allows simultaneous binding to Hsp70 and Hsp90 (5). These observations led to the hypothesis that STI1 acts as an adaptor protein to transfer client substrates between Hsp70 and Hsp90. Indeed, STI1 can regulate the ATPase activity of Hsp90 to help drive the sequential steps of the chaperone machinery (6). Recent structural work suggests that STI1 can maintain Hsp90 in an open conformation to receive client proteins recruited by Hsp70 (7). STI1 may also function as a scaffolding protein, for example, by linking Hsp90 to P-element-induced wimpy testis (Piwi), a process that regulates phenotype canalization in Drosophila (8).

STI1, similar to heat-shock proteins $(9,10)$, can also be secreted by cells. The protein is secreted by astrocytes via microvesicles exerting extracellular effects on neurons and astrocytes (11-13). Extracellular STI1 can form a signaling complex with the prion protein $\left(\mathrm{PrP}^{\mathrm{C}}\right)$ in hippocampal neurons to activate cellular signaling by increasing intracellular calcium via $\alpha 7$ nicotinic ACh receptors $(\alpha 7 \mathrm{nAChRs}$; ref. 14$)$. In other types of neurons, STI1 can also increase intracellular $\mathrm{Ca}^{2+}$ in a manner that is independent of $\alpha 7$ nAChRs (15). STI1/ $\operatorname{PrP}^{\mathrm{C}}$ engagement can protect hippocampal neurons against staurosporine-mediated cell death and also increase their differentiation $(4,16,17)$.

Elimination of STI1 does not affect growth in yeast, unless in the presence of Hsp90 mutants (18). In Caenorhabditis elegans, lack of STI1 is not lethal, but it decreases life span and increases sensitivity to stress (19). A number of cochaperones containing TPR domains, similar to those in STI1, interact with the MEEVD motif of Hsp90 (5); hence, it is possible that other cochaperones could substitute for STI1. In mammals, the in vivo roles of STI1 are not understood. Here, we targeted STI1 in mice and found that this protein is expressed early during development. Embryonic STI1 deficiency impairs survival of mice, and we show that several Hsp90 client proteins are reduced in STI1 mutant mice, suggesting that multiple Hsp90 clients may be affected in the absence of STI1. Early embryonic death of STI1-mutant mice could be rescued by transgenic expression of STI1, confirming that STI1 has unique cochaperone activity in mice. In adult mice, reduced levels of STI1 affected the response to cellular stress, demonstrated by the increased sensitivity of STI1 haploinsufficient mice to ischemic insult. We provide evidence that extracellular STI1 supports neuronal survival following ischemia and that this neuroprotective effect is lost in $\operatorname{PrP}^{\mathrm{C}}$-null neurons. These data suggest that STI1 is a multifunctional protein required during development, and in the absence of STI1, cells have decreased resilience to stress.

\section{MATERIALS AND METHODS}

\section{Mouse line generation}

Genetically modified mice were generated using standard homologous recombination techniques (20), using C57BL/6J ES cells. Mice were generated by Ozgene (Perth, Australia). Construct design is shown in Supplemental Fig. S1A. Chimeric mice were bred to $\mathrm{C} 57 \mathrm{BL} / 6 \mathrm{~J}$ mice, and germline transmission of the mutant STI1 allele was identified by Southern blot (not shown). F1 mice were then crossed to constitutive Cre mice to remove loxP-flanked regions. Cre-recombined mice were then crossed to $\mathrm{C} 57 \mathrm{BL} / 6 \mathrm{~J}$ mice, and progeny bearing the recombined STI1 allele, but lacking the Cre transgene, was identified by Southern blot analysis (not shown). These mice were then used to expand the colony. $S T I 1^{-/+}$mice were then intercrossed to generate $S T I 1^{-I^{-}}$ mice. We have attempted to generate mice with a conditional STI1-floxed allele; however, we found that after removal of the neocassete, this particular floxed allele was null and also caused embryonic lethality (results not shown).

The BMQ-41A8 bacterial artificial chromosome (BAC), a 56,549-bp DNA fragment from mouse chromosome 19 containing the STI1 gene, was obtained from Source BioScience Life Sciences (Nottingham, UK). The BAC was digested and analyzed using restriction enzymes. This BAC was then used to generate transgenic mice using standard techniques at the Jackson Laboratories (Bar Harbor, ME, USA) transgenic facility in a C57BL/6J background. In all experiments that involved quantification between genotypes, the experimenters were blinded to the genotypes.

\section{Ethics statement}

Animals were maintained and handled by the University of Western Ontario Animal Care and Veterinarian Service, or in the A. C. Camargo Hospital vivarium. Procedures were conducted in accordance with approved animal use protocols at the University of Western Ontario (2008/127) and the A. C. Camargo Hospital (037/09), and they were in accordance with the Canadian Council of Animal Care (CCAC) and U.S. National Institutes of Health (NIH) guidelines.

\section{Isolation of blastocysts and embryos}

Heterozygous STI1 females, aged 4 to $5 \mathrm{wk}$, were superovulated ( $5 \mathrm{IU}$ of pregnant mare serum gonadotropin followed $48 \mathrm{~h}$ later by 5 IU human chorionic gonadotropin) and mated with heterozygous STI1 males. Females were euthanized $3.5 \mathrm{~d}$ later, and the blastocysts were collected by uterine flushing using M2 medium (Sigma, Oakville, ON, Canada). Embryos were collected from timed pregnant females and were genotyped.

\section{RT-PCR and qPCR}

Samples [brain tissue, mouse embryos (E10) and astrocyte cultures] were homogenized in TRIzol, and total RNA was extracted using the Aurum Total RNA for fatty and fibrous tissue kit from Bio-Rad (Hercules, CA, USA). qRT-PCR and qPCR were performed as described previously $(21,22)$. A nontemplate reaction was used as a negative control for each experiment, and $\beta$-actin mRNA levels were used to normalize 
the data, as described previously. Sequences of primers used are shown in Supplemental Table S1.

\section{Astrocyte primary culture}

Astrocyte primary cultures were prepared as described previously (11). Briefly, cortical tissue from each individual embryo was dissociated in $5 \mathrm{ml}$ DMEM supplemented with $1 \%$ (v/v) penicillin/streptomycin and $10 \%$ FBS and plated in a $100-\mathrm{mm}$ cell culture dish. Cultures were maintained in an incubator at $37^{\circ} \mathrm{C}, 5 \% \mathrm{CO}_{2}$ for $10-12 \mathrm{~d}$, and the medium was replaced $1 \times /$ wk.

\section{Neuronal culture}

Primary cultures of hippocampal neurons from E17 pregnant females were obtained as described previously (17). Cultures from individual embryos were maintained separately. Neuronal cultures from control and PrPC-null mice were prepared as described previously (14).

\section{Mouse embryonic fibroblast (MEF) culture}

MEFs were prepared from E10.5 embryos as described previously (23). The cultures were obtained from each embryo, and the heads were used for genotyping. For survival curves, $2 \times 10^{4}$ cells were plated in duplicate into 24-well plates; to one of them, we added DMEM supplemented with $20 \%$ FBS, and to the other, we added half of the volume of the same medium with $40 \%$ of FBS and half of $2 \times$ concentrated conditioned medium (CM) from $S T I 1^{+/+}$MEFs. The medium was supplemented with recombinant STI1 $(2 \mu \mathrm{M})$.

\section{Western blot analysis}

Samples were homogenized in ice-cold RIPA buffer $(50 \mathrm{mM}$ Tris-HCl, pH 8; 150 mM NaCl; $1 \%$ Nonidet P-40; $1 \%$ sodium deoxycholate; and 1\% SDS), and the protein concentration was evaluated using protein assay reagent (Bio-Rad, Hercules, CA, USA). Protein (5-20 $\mu \mathrm{g})$ was loaded on each gel lane and transferred to membrane for Western blot analysis, as described previously (21). All blots were quantified using FluoChem (Alpha Innotech; GE Healthcare, London, ON, Canada) or ImageJ software (NIH, Bethesda, MD, USA).

\section{Oxygen and glucose deprivation (OGD)}

Neurons were plated in P35 $\left(5 \times 10^{5}\right.$ cells $)$ dishes, and the cultures were kept under the conditions described above until the medium was changed after 7 days in vitro (DIV). Cells were submitted to OGD by using a chamber to control the levels of oxygen $(0.5 \%)$ and $\mathrm{CO}_{2}(5 \%)$ for $1 \mathrm{~h}$, and the neurons were kept in glucose-deficient neurobasal medium just prior to the hypoxia treatment. After OGD, the glucosefree medium was replaced with regular medium with or without recombinant STI1 $(1 \mu \mathrm{M})$, and the cells were returned to normal oxygen conditions for $24 \mathrm{~h}$.

Astrocytes were plated in P35 dishes. After $70 \%$ of confluence, the cells were deprived of FBS for $48 \mathrm{~h}$, after which a medium change was performed. Astrocytes were submitted to OGD in glucose-deficient DMEM. For the secretion experiments, medium was collected after $9 \mathrm{~h}$ of OGD. In control cells, medium was collected after $9 \mathrm{~h}$ of incubation, as described below, and used in Western blots to detect secreted STI1. For the cell death assay, glucose-free medium was replaced with regular medium, and cells were returned to normal oxygen conditions for $48 \mathrm{~h}$.

\section{Secretion of STI1 in CM}

Astrocytes or fibroblasts were plated in P60 dishes as described above. After $90 \%$ of confluence, the cells were deprived of FBS for $48 \mathrm{~h}$. Culture medium was then collected and centrifuged at $10,000 \mathrm{~g}$ for $20 \mathrm{~min}$ at $4^{\circ} \mathrm{C}$, and the supernatant was used as CM.

\section{Micro-computed tomography (micro-CT)}

For micro-CT, embryos were harvested at E10.5 and fixed in $10 \%$ formalin in PBS ( $48 \mathrm{~h}$ at $4^{\circ} \mathrm{C}$ ), then immersed in Lugol

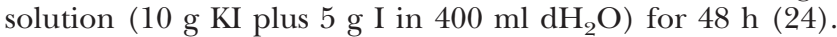
The Lugol solution acted as a micro-CT contrast agent. Scanning was performed using a GE Locus SP scanner (GE Healthcare) using the following scan parameters: $80 \mathrm{kVp}$ with $0.508-\mathrm{ml} \mathrm{Al}$ filtration, $80 \mu \mathrm{A}, 900$ views over $360^{\circ}$; 4 frames averaged, with images reconstructed to yield $13-\mu \mathrm{m}$ isotropic voxels (25).

\section{Hematoxylin and eosin (H\&E) staining}

Embryos (E10.5) were harvested, formalin fixed (10\% formalin for $48 \mathrm{~h}$ at $4^{\circ} \mathrm{C}$ ), and paraffin embedded. Sections (3-5 $\mu \mathrm{m})$ were deparaffinized and stained with $\mathrm{H} \& \mathrm{E}$. Images were acquired with an Olympus DP72 camera using cellSens Dimension software (Olympus, Tokyo, Japan).

\section{Immunofluorescence}

Astrocytes $\left(1 \times 10^{5}\right.$ cells $)$ and fibroblasts $\left(1 \times 10^{5}\right.$ cells $)$ were grown on coverslips. Cells were fixed in $4 \%$ paraformaldehyde/PBS for $20 \mathrm{~min}$ and washed in PBS Triton X-100 $(0.05 \%)$ solution followed by blocking in PBS with $0.05 \%$ TritonX-100 plus $10 \%$ of normal goat serum. Cells were incubated with anti-STI1 (1:400), anti-Hop (1:100; Enzo Life Sciences, Farmingdale, NY, USA), anti-STI1 (1:100; Sigma), anti- $\beta$-tubulin (1:100; Sigma), or anti- $\gamma$-H2AX (1:100; Cell Signaling, Boston, MA, USA) overnight at $4^{\circ} \mathrm{C}$.

The deciduae containing E6.5 embryos were dissected, fixed overnight at $4{ }^{\circ} \mathrm{C}$ in $4 \%$ paraformaldehyde, and cryoprotected with $0.1 \mathrm{M}$ phosphate buffer ( $\mathrm{pH} 7.4$ ) containing $30 \%$ sucrose. Whole deciduae were frozen with dry ice, and cryostat sections $(10 \mu \mathrm{m})$ were obtained and mounted on silanized slides. E10.5 embryos were harvested, formalin fixed $\left(10 \%\right.$ formalin for $48 \mathrm{~h}$ at $4^{\circ} \mathrm{C}$ ), and paraffin embedded. Sections $(3-5 \mu \mathrm{m})$ were deparaffinized. For immunofluorescence, tissues were incubated with blocking solution $(0.1 \mathrm{M}$ phosphate buffer, $\mathrm{pH} 7.4$, containing $0.2 \%$ Triton X-100 plus $20 \%$ goat serum) for $1 \mathrm{~h}$ at room temperature, followed by overnight incubation with anti-rabbit STI1 antibody (1:200) or anti-rabbit caspase 3 activated (1:200). Tissues were washed $3 \times$ with PBS and anti-rabbit Alexa Fluor 488 plus TO-PRO3 iodide $(1: 1000)$ or Hoechst $(1: 1000)$ for nuclei staining for 1 $\mathrm{h}$ at room temperature. Slides were mounted on coverslips using Fluorsave (Calbiochem, La Jolla, CA, USA) and imaged using a Leica TCS SP5 II laser scanning confocal system or Zeiss LSM-510 confocal microscope (Carl Zeiss, Oberkochen, Germany).

\section{Cell death assay}

Neuronal and astrocyte cell death assays were performed using the Live/Dead viability/cytotoxicity kit for mammalian cells (Invitrogen, Oakville, ON, Canada) as described in the manual. Counting was done using ImageJ software and cal- 
culated as percentage of dead cells [number of dead cells/ (number of dead cells + viable cells $) \times 100]$.

\section{Middle cerebral artery occlusion (MCAO)}

Anesthesia was induced by inhalation of $4 \%$ isoflurane (in $\mathrm{O}_{2}$ ), and maintenance was done by inhalation of $1.5 \%$ isoflurane. A modification of a previously described method (26) for transient intraluminal MCAO was used. Under an operating microscope, a monofilament nylon suture (diameter 0.06-0.09 mm; Doccol Corp., Redlands, CA, USA) was inserted through the left common carotid artery into the internal carotid artery and then into the circle of Willis, effectively occluding the MCA for $60 \mathrm{~min}$. Sham-treated animals underwent the same procedure, with the exception of the advancement of the filament to occlude the cerebral artery. After filament insertion, the mice were removed from anesthesia and kept at $37^{\circ} \mathrm{C}$ under a heat lamp freely moving during $1 \mathrm{~h}$ of occlusion. Mice were then anesthetized again, and the filament was quickly removed. At $1 \mathrm{~h}$ after surgery, mice were injected i.p. with saline to maintain hydration. This procedure was repeated again, if necessary, on the basis of weight recovery of the animal and clinical assessment score. Food pellets were wetted and kept on the floor of the cage for recovering mice. Neurological assessment was performed 1, 24 , and $48 \mathrm{~h}$ after surgery following scores modified from the 5-point Bederson scale (27): 0, no deficit; 1, mild forelimb weakness; 2 , severe forelimb weakness, consistent turns to the deficit side when lift by the tail; 3, compulsory circling; 4, unconscious; 5 , dead. Only mice that scored 2 or 3 were used in the experiments. Heart rate data were obtained under baseline and during the MCAO period (30 min postocclusion) in conscious mice using the CODA computerized noninvasive system (Kent Scientific, Torrington, CT, USA). Rectal temperature was monitored by a homeothermic blanket control unit (Harvard Apparatus, Holliston, MA, USA). Arterial blood samples (obtained via cardiac puncture under isoflurane anesthesia) were taken at baseline or at the end of the MCAO period and analyzed for $\mathrm{pH}$ and glucose using a blood analyzer (ABL-725; Radiometer, Copenhagen, Denmark).

\section{Magnetic resonance imaging (MRI)}

An Agilent (Palo Alto, CA, USA) 9.4-T small-animal horizontal-bore MRI system was used to acquire images of the mouse brain $24 \mathrm{~h}$ after MCAO. Two imaging sequences were used to visualize tissue damage due to ischemia: a $T_{2}$-weighted 2-dimensional fast spin echo (FSE) sequence $\left(T_{E}=45 \mathrm{~ms}, T_{R}=\right.$ $3000 \mathrm{~ms}$, FOV $19.2 \times 19.2 \mathrm{~mm}, 31$ slices, slice thickness $=500$ $\mu \mathrm{m}$, acquisition matrix $128 \times 128$ ) and a 3-dimensional bal- anced steady-state free precession (bSSFP) sequence $\left(T_{E}=3.7\right.$ $\mathrm{ms}, T_{R}=7.4 \mathrm{~ms}$, FOV $19 \times 16 \times 13 \mathrm{~mm}$, acquisition matrix $154 \times 132 \times 102)$. Infarct volume was measured by manual tracing of the hyperintense tissue in each slice of the $T_{2}$ images using Image J by a single investigator blinded to the genotypes (D.G.).

\section{Adhesive removal}

Postischemic and sham-treated animals were subjected to behavioral tests $7 \mathrm{~d}$ after stroke. The adhesive removal test is sensitive to unilateral somatosensory dysfunction and was used to determine functional recovery (28). Three trials were conducted and averaged per day. Individual trials were separated by at least $15 \mathrm{~min}$.

\section{RESULTS}

\section{Mouse STI1 (Stip1) deficiency causes embryonic lethality}

To uncover potential in vivo roles of STI1 in mammals, we generated a Stip1-knockout mouse line (Supplemental Fig. S1A). The strategy used the Cre/Lox system to remove exons 2 and 3 from a floxed Stip1 allele. This deletion truncated the STI1-coding region and created a stop codon close to the initial ATG, so that the protein expression was abolished. Sequencing of the targeted Stip1 allele $\left(S T I 1^{-}\right)$confirmed the genetic manipulation. We found that embryos containing 2 $S t i 1^{-}$alleles died around E9.5-E10.5 (Table 1). Further analysis of $S T I 1^{+/-}$intercrosses revealed that recovery of $S T I 1^{-/-}$embryos did not follow Mendelian frequency. The reduced frequency observed (9 and 12\% instead of 25\% for E3.5 and E10.5, respectively; Table 1), suggested that $S T I 1$ deficiency affected the survival of embryos prior to implantation.

To test the possibility that STI1 is expressed early during development, we immunolabeled blastocysts (E3.5) with a STI1 antibody. Immunoreactivity for STI1 was easily detected in blastocysts. Surprisingly, substantial labeling for STI1 was also detected in $S T I 1^{-/-}$ blastocysts, although at lower levels than observed in wild-type blastocysts (Fig. 1A). Similar results were obtained with two other commercial STI1 antibodies (not shown). All blastocysts had their genotypes con-

TABLE 1. Viability analysis of $S T I 1^{-1-}$ mice and embryos ${ }^{\mathrm{a}}$

\begin{tabular}{lcccrr}
\hline \hline \multirow{2}{*}{ Stage } & \multicolumn{4}{c}{ Number with genotype } \\
\cline { 2 - 4 } & $S T I 1^{+/+}$ & $S T I 1^{-/+}$ & $S T I 1^{-/-}$ & Reabsorbed & Total \\
\hline Live birth & 65 & 103 & $0^{* * *}$ & 0 & 168 \\
E17.5 & 33 & 42 & $0^{* * *}$ & 21 & 96 \\
E13.5 & 14 & 22 & $0^{* * *}$ & 16 & 52 \\
E10.5 & 68 & 131 & $27(12 \%)^{a, * * *}$ & 68 & 294 \\
E3.5 & 47 & 57 & $16(13 \%)^{a * *}$ & 0 & 120 \\
\hline
\end{tabular}

Genotypes were determined by PCR as described in Materials and Methods. Empty deciduas were scored as reabsorbed. ${ }^{a} S T I 1^{-\prime-}$ ratio. Data were analyzed by $\chi^{2}$ test, comparing the expected and observed frequencies for each genotype at different time points of embryonic development. $* P \leq 0.05$, $* * * P \leq 0.0005$. 
A
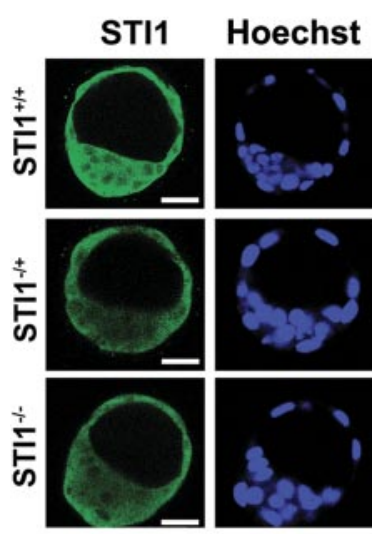

E CDX2
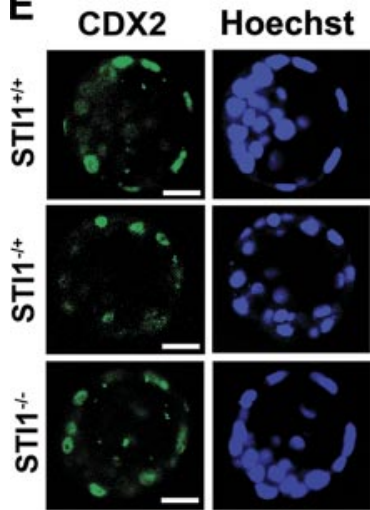

B

$\mathrm{STI1}^{+1+} \mathrm{STI1}^{1++} \mathrm{STI1}{ }^{1+}$

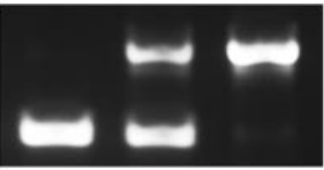

$400 \mathrm{bp}$

$200 \mathrm{bp}$
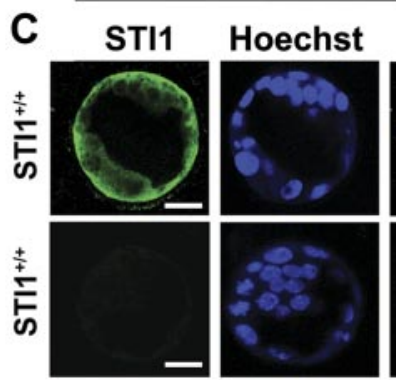

Merge
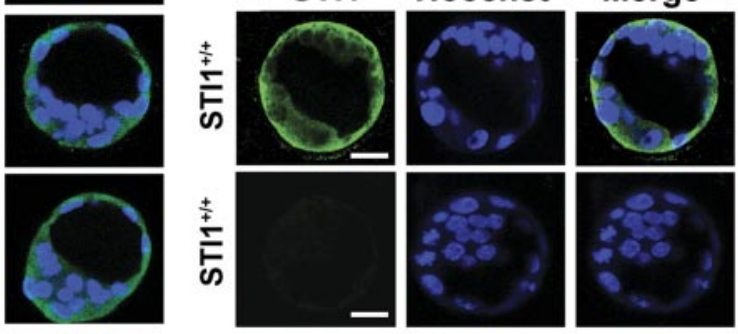

Figure 1. Expression of STI1, Oct4, and CDX2 in mouse blastocysts. A) STI1 labeling (green) in $S T I 1^{+/+}, S T I 1^{-/+}$, and $S T I 1^{-/-}$blastocysts (representative images of $24 S T I 1^{+/+}, 22 S T I 1^{+/-}$, and $8 S T I 1^{-/-}$blastocysts). Nucleus is shown in blue. Scale bars $=20 \mu \mathrm{m}$. B) Agarose gel showing an example of blastocyst genotyping. C) Control experiments for STI1 antibody specificity. Antibody was incubated (bottom panels) or not (upper panels) with recombinant STI1 and then used to label $S T I 1^{+/+}$blastocysts. D) Labeling for the pluripotency marker Oct4 (green) in $S T I 1^{+/+}, S T I 1^{-/+}$, and $S T I 1^{-{ }^{-}}$blastocysts (representative images of $13 S T I 1^{+/+}, 23 S T I 1^{-/+}$, and $4 S T I 1^{-/-}$). E) Labeling for marker of trophoblast-committed cells, CDX2 (green), in $S T I 1^{+/+}, S T I 1^{-/+}$, and $S T I 1^{-/-}$ blastocysts (representative images of $13 \mathrm{STI1}^{+/+}, 25 \mathrm{STI1}^{-/_{+}^{+}}$, and $5 \mathrm{STI1}^{-/^{-}}$). Scale bars $=20 \mu \mathrm{m}$.

firmed by PCR after immunostaining (Fig. 1B). Control experiments showed that immunolabeling with the STI1 antibody was completely abolished by absorption with excess recombinant STI1 (Fig. 1C), indicating that STI1 labeling in blastocysts was specific. Since there are no other STI1 homologs, these results suggest that maternal STI1, deposited either as protein or mRNA, is present in blastocysts and may play a role in early embryonic development.

Given the early expression of STI1 in blastocysts and lethality of $S T I 1^{-/-}$embryos, we tested whether genes critical for embryonic development might be altered in blastocysts. We did not observe a difference in the expression of the pluripotency marker Oct 4 between wild-type and $S T I 1^{-/-}$blastocysts (Fig. $1 D$; all blastocysts were genotyped for STI1 alleles after immunostaining). Moreover, CDX2 labeling, used to probe for trophoblast-committed cells, was similarly expressed in control and STI1-deletion mutants (Fig. 1E).

Immunoblot analysis of individual embryos at the last developmental stage in which we could find $S T I 1^{-/-}$ mice (E10.5) demonstrated that protein extracts $(5 \mu \mathrm{g}$ of protein) from $S T I 1^{-/+}$embryos showed $50 \%$ reduction in STI1 levels, while no STI1 immunoreactivity was observed in $S T I 1^{-/-}$extracts (Fig. 2A). However, when we loaded the gel with a higher amount of protein (20 $\mu \mathrm{g})$, we were able to detect small quantities of STI1 in $S T I 1^{-/-}$extracts (20\%; Fig. 2B). Moreover, by immunofluorescence, we observed weak immunolabeling for STI1 in sections of $S T I 1^{-/-}$embryos (E10.5; Fig. $2 C$ ).
We quantified STI1 mRNA in STI1 ${ }^{-/-}$E10.5 embryos by RT-PCR and qPCR. Our results shown that no STI1 mRNA is present in $S T I 1^{-/-}$E10.5 embryos (Fig. 2D), suggesting that the immunoreactivity that we detected in embryos might originate from extraembryonic sites.

Interestingly, we found high levels of STI1 present at extraembryonic sites in wild-type embryos, specifically at the trophoblast layer (Fig. 2E). Whether this extraembryonic STI1 may contribute for survival of mutant embryos during the early developmental stage is currently unknown. In addition, we observed the presence of acute inflammation in and around the labyrinth in the placenta from $S T I 1^{-/-}$embryos (Fig. 2F), suggesting that their placenta has had a vascular disruption, as there was no evidence of infection. Hence, placental disruption might facilitate the transfer of maternal STI1 to embryos but could also contribute to embryonic dysfunction. STI1 has been shown to be secreted by distinct cell types $(11,29,30)$, including ovarian cells $(31,32)$ and has also been found in plasma $(31)$.

To understand the characteristics of embryonic development in STI1-mutant mice, we performed micro-CT analysis. This experiment demonstrated that neural tube and limb buds were poorly formed in $S T I 1^{-/-}$embryos (Fig. 3A). In addition, histochemistry analysis showed that $S T I 1^{-/-}$embryos presented a great number of cells that were undergoing apoptotic cell death, characterized by increased levels of activated caspase-3 (Fig. $3 B$ ), as well 

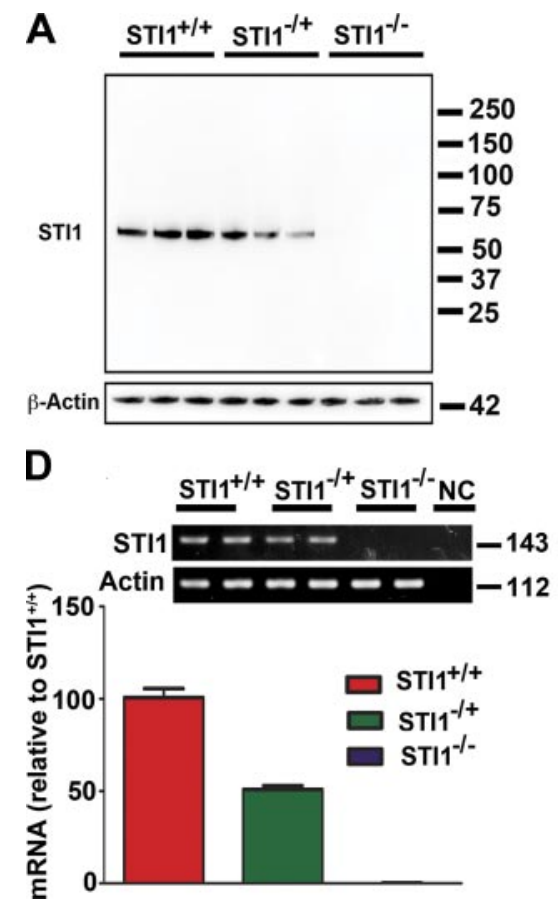

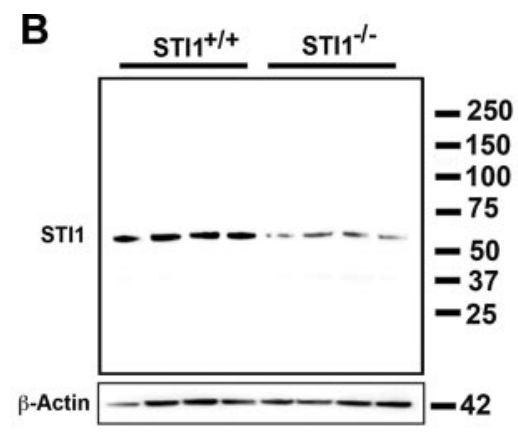

E

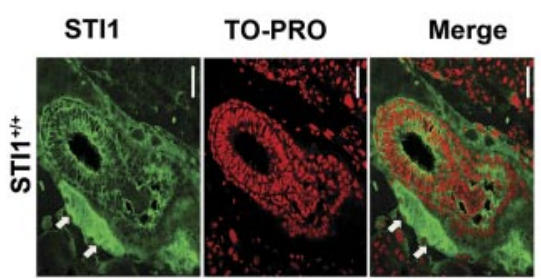

C

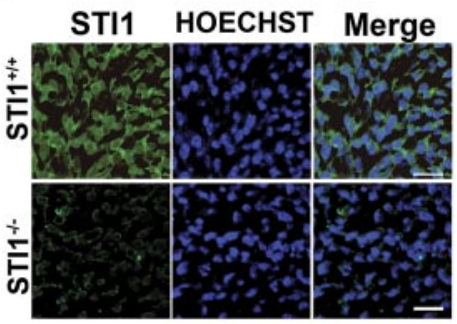

$\mathbf{F}$

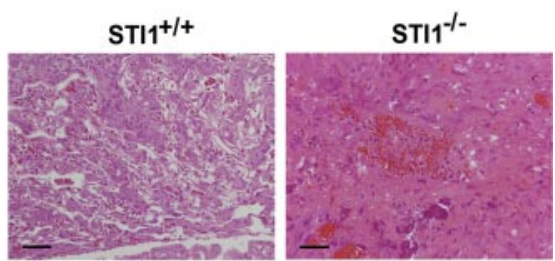

Figure 2. STI1 expression in embryos. A, B) Western blot analysis of STI1 in $S T I 1^{+/+}, S T I 1^{-/+}$, and $S T I 1^{-/-}$embryos at E10.5 ( 5 and $20 \mu \mathrm{g}$ of protein, respectively; protein extracts from 5 embryos for each genotype in $A$ and 4 embryos for each genotype in $B$ ). Molecular mass markers are shown on the side; actin was used as a loading control. $C$ ) Immunofluorescence analysis of STI1 expression (green) in $S T I 1^{+/+}$and $S T I 1^{-/-}$in mouse embryos (E10.5). Nuclei were stained with the nuclear marker Hoechst (blue). Scale bars $=20 \mu \mathrm{m} . D$ ) STI1 mRNA expression by RT-PCR (top gel) and qRT-PCR (bar graph) in ST1 ${ }^{+/+}, S^{2} T 1^{-/+}$, and $S T I 1^{-/-}$embryos (E10.5; $n=4$ embryos/genotype). E) Immunofluorescence of $S T I 1^{+/+}$mouse embryo (E6.5) showing high levels of STI1 (green) at extraembryonic sites (arrows). Note that STI1 staining in $S T I 1^{+/+}$embryo is much stronger than in deciduas (tissue from $S T I 1^{-/+}$mother). Nuclei were stained with the nuclear marker TO-PRO (red). Scale bars $=75 \mu \mathrm{m}$. F) Placental staining using H\&E from E10.5 STI1 ${ }^{-/-}$mouse embryos (representative H\&E images from 2 embryos/genotype).

Scale bars $=200 \mu \mathrm{m}$.

as pyknotic apoptotic bodies with a hypereosinophilic cytoplasm in H\&E (Fig. $3 C-H)$.

The early embryonic death with increased apoptosis in STI1-mutant mice is unexpected, given that elimination of STI1 in yeast (32) and C. elegans is not lethal (19). To test the possibility that the cochaperone activity of STI1 is required during development, we examined the expression levels of 3 distinct Hsp90 client proteins. Immunoblot analysis showed that Hsp90 levels were unchanged in $S T I 1^{-/}$mice (Fig. $4 A, B$ ). In contrast, the levels of G-protein-receptor kinase 2 (GRK2), signal transducer and activator of transcrip-
A

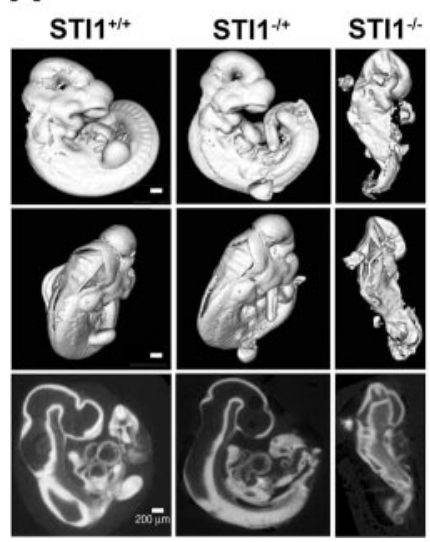

B
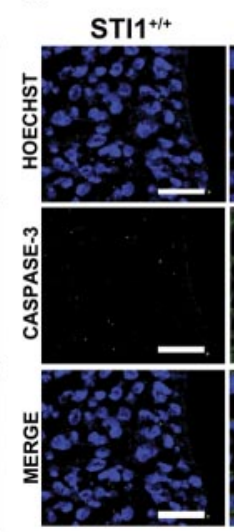

STI1 ${ }^{\text {- }}$
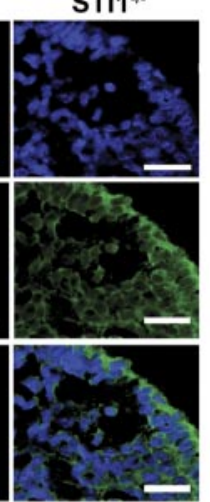
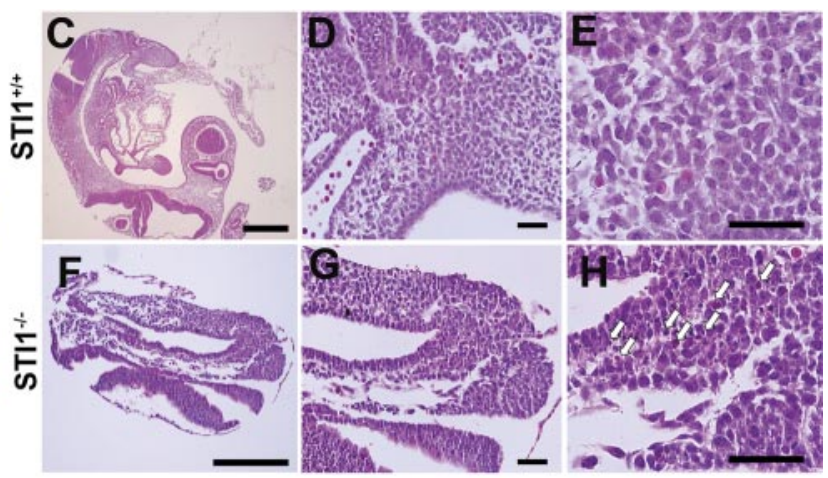

Figure 3. Embryonic STI1 deficiency affects development. A) Micro-CT analysis of $S T I 1^{+/+}, S T I 1^{-/+}$, and $S T I 1^{-/-}$ mouse embryos (E10.5). Micro-CT images (bottom panel) were used for 3-dimensional reconstruction of embryos; images in top and middle panels are surface renderings showing different angles (representative images of 4 embryos/genotype). $B$ ) Levels of activated caspase-3 (green) in E10.5 tissue. $C-H$ ) Morphological analyses of E10.5 embryos stained with H\&E showing elevated number of cells with pyknotic nuclei and hypereosinophilic cytoplasm, indicating apoptotic cells in $S T I 1^{-1-}$ embryos (arrows indicate pyknotic nuclei; representative images of 3 embryos/genotype). Scale bars $=200 \mu \mathrm{m}$ $(A) ; 500 \mu \mathrm{m}(C, F) ; 50 \mu \mathrm{m}(B-G)$. 
A

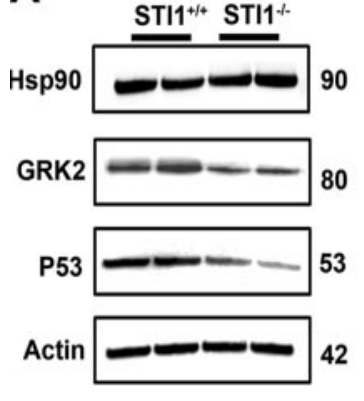

B

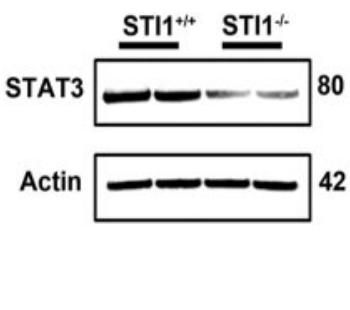

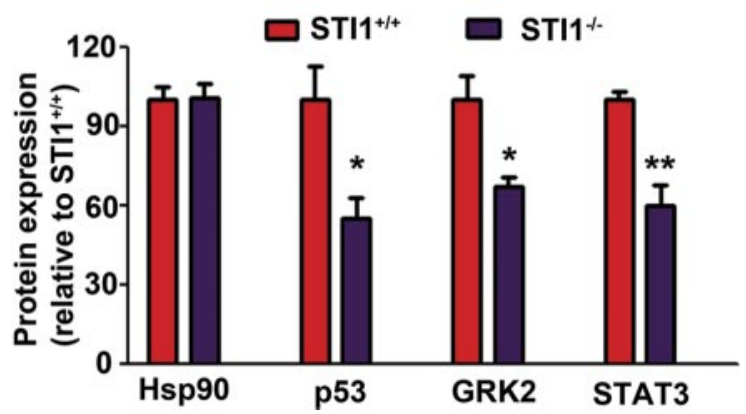

Figure 4. Analysis of protein expression in $S T I 1^{-/-}$E10.5 embryos. A) Western blot analysis of Hsp90, GRK2, p53, and STAT3 in $S T I 1^{+/+}$and $S T I 1^{-/-}$embryos at E10.5 (20 $\mu$ g protein). B) Quantification of protein expression from Western blots (protein extracts from 4 embryos/genotype for GRK2 and p53; 7 embryos/genotype for Hsp90 and STAT3). Results are presented as means \pm SE. $* P<0.01, * * P<0.001$; Student's $t$ test.

tion 3 (STAT3), and protein 53 (p53), all Hsp90 client proteins (33-35) were significantly reduced to almost $50 \%$ (Fig. $4 A, B$ ).

To further understand the consequences of interference with Stip1 for cellular function, we cultured MEFs from E10.5 embryos. During the initial days in culture, we could not distinguish wild-type from $S T I 1^{-/-}$cells using morphological criteria. However, after a few days, we noticed that $S T I 1^{-/-}$MEFs were dying, whereas wild-type or $S T I 1^{-/+}$MEFs thrived well in culture $($ Fig. $\mathbf{5 A}, \boldsymbol{B})$. Interestingly, most $S T I 1^{-/-}$ MEFs had died off following $8-10 \mathrm{~d}$ in culture (Fig. $5 A$, $B)$. To understand potential causes of this increased lethality in $S T I 1^{-/-}$MEFs, we labeled these cells during the first $2 \mathrm{~d}$ of culture with an antibody against $\gamma$-H2AX, a phosphorylated histone recruited to sites of DNA double-strand breaks in response to distinct cellular stresses (36). Wild-type MEFs showed no labeling for $\gamma$-H2AX (Fig. 5C); however, STI1 ${ }^{-/-}$MEFs presented widespread nuclear foci labeling (Fig. $5 C$ ), suggestive of increased cellular stress levels. Interestingly, $S T I 1^{-/+}$ MEFs also presented $\gamma$-H2AX labeling (Fig. 5C). Since enhanced cellular stress levels increase DNA damage, which may affect cell cycle (37), we examined proliferation of $S T I 1^{-/-}$MEFs and found decreased proliferation, as compared to $S T I 1^{-/+}$or $S T I 1^{+/+}$MEFs (Fig. $5 D$ ). Hence, $S T I 1^{-/-}$MEFs were impaired in cellular proliferation and showed increased levels of cellular stress, which likely affected cellular viability.

We examined STI1 expression in MEFs and found that $S T I 1^{-/-}$MEFs presented weak nuclear immunolabeling for STI1 (Fig. 5C). Immunolabeling in STI1 ${ }^{-/-}$ MEFs was specific because the same pattern of STI1 immunolabeling was observed with distinct antibodies (Supplemental Fig. S1B); STI1 immunolabeling in MEFs and other cells could be absorbed with excess recombinant STI1 (Supplemental Fig. S1C); and the main antibody that we used in these experiments recognizes only one band in immunoblots with the correct molecular mass in embryos or in brain extracts of adult $\mathrm{STII}^{+/+}$and $S T I 1^{-/+}$mice (Fig. $2 A, B$ and Supplemental Fig. S1D). Hence, it is likely that MEFs containing some maternal STI1 may have been selected to survive longer in these cultures.

The weak STI1 labeling was concentrated mostly in the nucleus in $S T I 1^{-/-}$MEFs (Fig. 5C), as opposed to the predominantly cytoplasmic labeling observed in wild-type MEFs and in blastocysts (see Fig. 1A). Fibroblasts obtained from $S T I 1^{-/+}$MEFs, which presented overall weaker labeling than wild-type MEFs, also showed increased nuclear labeling for STI1 (Fig. $5 C$ ). This increased level of nuclear STI1 is likely related to increased levels of cellular stress, as stress has been shown to increase nuclear accumulation of STI1 (38). STI1 has been previously shown to have a nuclear localization signal (NLS; refs. 38, 39). Given that wildtype MEFs secrete STI1 (Fig. $5 F$ ), we examined whether increasing levels of extracellular STI1 could perhaps attenuate the lethality observed in $S T I 1^{-/-}$MEFs. We incubated $S T I 1^{-/-}$MEFs with CM obtained from wildtype MEFs supplemented with $2 \mu \mathrm{M}$ recombinant STI1 (Fig. 5E). Lethality of $S T I 1^{-\prime-}$ MEFs could not be rescued by increasing extracellular levels of STI1 or by other factors secreted by wild-type MEFs in this condition. This result suggests that extracellular STI1 is not sufficient to maintain mutant MEFs viability.

\section{Rescue of lethality in $S T I 1^{-/-}$mice}

Given the presence of small amounts of extraembryonic STI1 in STI1-mutant mice, we decided to test further the requirement for embryonic STI1 during development. For this experiment, we initially generated STI1 transgenic mice, which were crossed with $S T I 1^{-/+}$, and tested for rescue of lethality of $S T I 1^{-/-}$ mice. Since STI1 appears to be required prior to implantation for survival of blastocysts, we used BAC containing the STI1 gene to generate transgenic mouse lines and reproduce any required early expression of STI1 during embryogenesis. We generated two distinct lines of STI1 BAC transgenic mice (STI1-TgA and STI1-TgC) presenting 10 and 2 extra alleles of STI1, respectively, as determined by qPCR (Fig. 6A). STI1 mRNA levels were increased 5-fold in STI1-TgA line compared to wild-type littermates (Fig. 6B), and pro- 

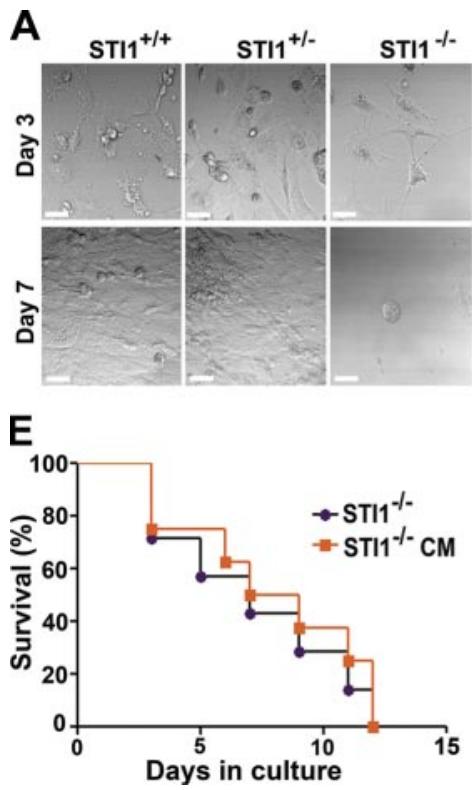

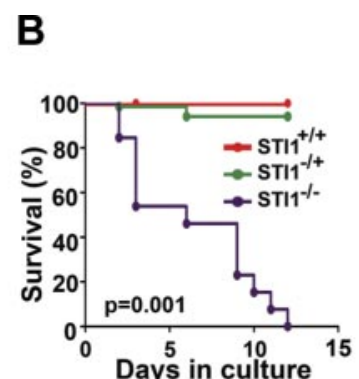

$\mathbf{F}$

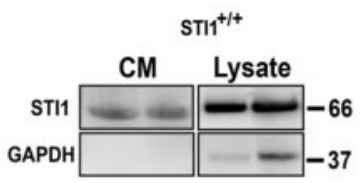

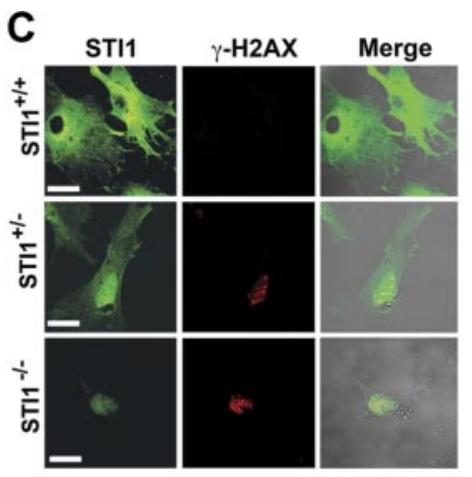

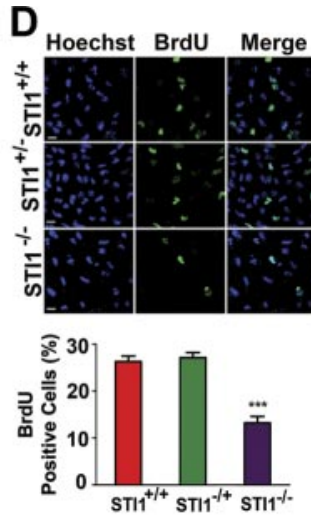

Figure 5. Survival and stress levels of $S T I 1^{-/-}$MEFs. A) Images of MEFs obtained from $S T I 1^{+/+}, S T I 1^{-/+}$, and $S T I 1^{-/-}$ embryos (E10.5) at $\mathrm{d} 3$ and 7 in culture (representative images of MEF cultures obtained from embryos: 32 $S T I 1^{+/+}, 67 S T I 1^{-/^{+}}$, and $\left.13 S T I 1^{-{ }^{-}}\right)$. Scale bars $=100$ $\mu \mathrm{m}$. B) MEF survival curves $\left(32 S T I 1^{+/+}, 67 S T I 1^{-/+}\right.$, and $13 S T I 1^{-{ }^{-}}$). C) Expression of STI1 (green) and $\gamma$-H2AX (red) in MEFs (representative images of MEFs obtained from independent cultures of 4 embryos/genotype). Scale bars $=$
$20 \mu \mathrm{m} . D$ ) Cellular proliferation determined by BrdU staining (green) in STI1 (independent cultures from 5 embryos/genotype). Scale bars $=20 \mu \mathrm{m}$. Top panel: representative images. Bottom panel: quantification of BrdU-positive cells. E) Survival curves of $S T I 1^{-/-}$MEFs growing in $S T I 1^{+/+}$CM supplemented with $2 \mu M$ recombinant STI1 (independent MEF cultures from $5 S T I 1^{-/-}$embryos). F) STI1 secretion by $S T I 1^{+/+}$MEFs. Survival curves were analyzed by log-rank test (Mantel-Cox; $P=0.0001$ between $S T I 1^{+/+}$, and $S T I 1^{-/-}$). Cellular proliferation is presented as means $\pm \mathrm{SE}$. $* * * P<0.0001 ; 1$-way ANOVA and Neuman-Keuls post hoc test.

tein level was also increased 4-fold in this transgenic line (Fig. 6C). In contrast, STI1-TgC line did not show increased levels of STI1 mRNA or protein (Fig. $6 B, D$ ), suggesting that in this second transgenic mouse line the BAC is transcriptionally silent. We crossed STI1-TgA and STI1-TgC lines with $S T I 1^{-/+}$, and then we interbred their offspring. We could not detect $S T I 1^{-}$alleles in crosses of STI1-TgC (0 STI1 ${ }^{-/-}$TgC pups out of 44 pups born from $S T I 1^{+/-} \mathrm{TgC}^{+} \times S T I 1^{+/-} \mathrm{TgC}^{-}$breeding), supporting the notion that this line did not express BAC-derived STI1. In contrast, STI1-TgA BAC expression was sufficient to rescue $S T I 1^{-/-}$mice (11 $S T I 1^{-/-}$TgA pups out of 52 pups born from $S T I 1^{+/-}$ $\mathrm{TgA}^{+} \times S T I 1^{+/-} \mathrm{TgA}^{-}$breeding). Figure $6 E$ shows the presence of $S T I 1^{-}$alleles in adult mice from STI1-TgA crosses detected by qPCR.

\section{Decreased levels of STI1 increased cellular stress and vulnerability to ischemia}

During development, the absence of embryonic STI1 increased cellular stress and vulnerability of cells. To determine whether altered levels of STI1 influence cellular resilience, we investigate stress levels in astrocytes. $S T I 1^{-/+}$astrocytes showed $\sim 50 \%$ decrease in STI1 levels (Fig. 7A), and they secreted less STI1 than their control counterparts (Fig. $7 B$ ). As observed for $S T I 1^{-/+}$MEFs (and also for $S T I 1^{-/-}$MEFs), STI1 was present mainly in the nucleus of a large number of $S T I 1^{-/+}$astrocytes (Fig. 7C), compared to the cytoplasmic localization of STI1 in wild-type astrocytes. Subcellular fractionation confirmed increased STI1 localization in the nucleus of $S T I 1^{-/+}$astrocytes (Supplemental Fig
S2A, B). Decreased levels of STI1 in $S T I 1^{-/+}$astrocytes did not affect cell cycle (Supplemental Fig. S2C, D) or astrocyte proliferation (Supplemental Fig. S2E$G)$. However, in agreement with the data obtained with MEFs, mutant astrocytes presented an increase in foci number per cell, detected by $\gamma$-H2AX staining (Fig. $7 D)$.

To examine whether reduced levels of STI1 affects the capacity of mice to respond to cellular stress and injury, we used a model of ischemic insult. We submitted $S T I 1^{-/+}$and wild-type mice to the middle cerebral artery occlusion (MCAO, $60 \mathrm{~min}$ ) technique to induce unilateral stroke. Sham-operated mice from both genotypes showed no signs of stroke and survived well after the surgery, independent of genotype (Fig. 8A). We detected no differences between genotypes in physiological parameters due to MCAO (Table 2). Whereas most wild-type mice survived after stroke injury $(20 \%$ lethality rate), $S T I 1^{-/+}$mice, however, displayed increased mortality and nearly $50 \%$ of the mice died $5 \mathrm{~d}$ following surgery (Fig. 8A). STI1 mutant mice showed increased brain infarct volume when compared to wild-type mice $24 \mathrm{~h}$ following MCAO (Fig. $8 B$ ). We tested whether $S T I 1^{-/+}$mice that survived the stroke injury recovered similarly to wild-type mice. Both genotypes lost weight just after surgery, but recovered after 7 d (Fig. 8C). Interestingly, behavioral analysis demonstrated that $7 \mathrm{~d}$ after MCAO, STI1 ${ }^{-/+}$mice performed poorly compared to wild-type mice in the tape removal test used to evaluate fine sensorimotor function (28). Both genotypes showed a clear deficit to perceive and remove the tape in the contralateral (right paw, RP), 


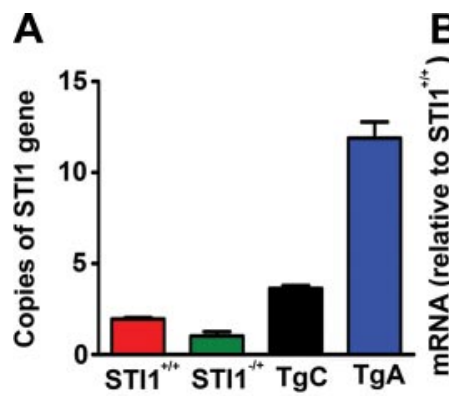

E

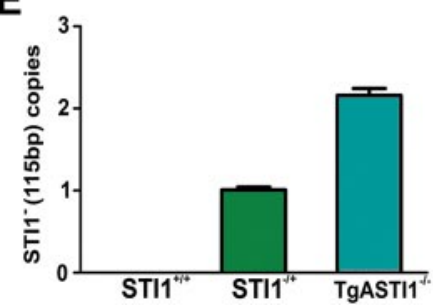

B

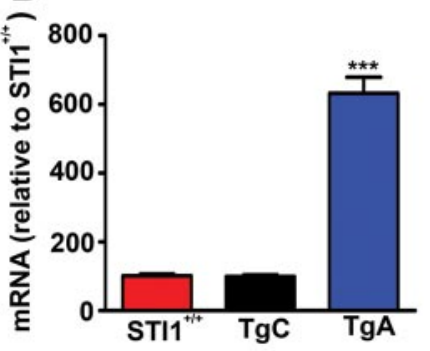

C

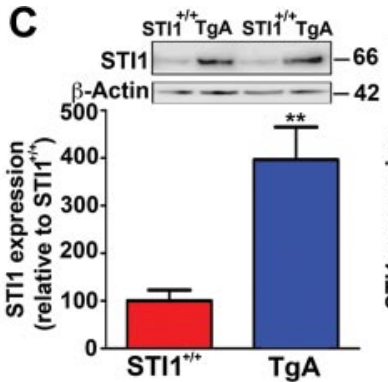

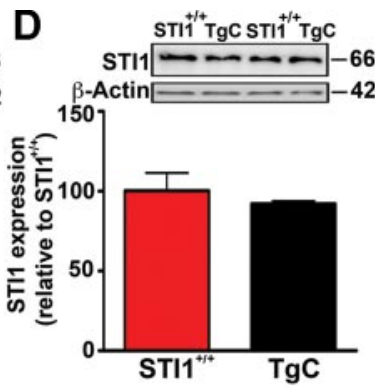

Figure 6. Rescue of embryonic lethality of $S T I 1^{-/-}$mice by transgenic expression of STI1. A) Number of copies of the STI1 gene in genomic DNA from $S_{T I 1^{+/+}}(n=8)$ and $S T I 1^{-/+}$mice $(n=4)$, as well as transgenic mouse lines STI1-TgA $(n=4)$ and STI1-TgC $(n=5)$. B) STI1 mRNA expression in the brain of $S T I 1^{+/+}$mice $(n=9)$ and transgenic lines STI1-TgA $(n=4)$ and STI1-TgC $(n=4)$. C) Representative immunoblotting and STI1 protein expression quantification in the brain of ST1 $1^{+/+}(n=4)$ and STI1-TgA mice $(n=4)$. D) Representative immunoblotting and STI1 protein expression quantification in the brain of ST1 ${ }^{+/+}(n=4)$ and STI1-TgC mice $(n=4$ mice). E) qPCR to determine the number of copies of the $S T I 1^{-}$allele (which is absent in wild-type mice) in tissue from adult mice, showing that expression of BAC-STI1 allowed survival of $S T I 1^{-/-}$mice $\left(4 S T I 1^{+/+}, 11^{S T I 1^{-/+}}\right.$, and $\left.5 \operatorname{TgASTI1}^{-{ }^{-}}\right)$. Results are presented as means \pm SE; data were analyzed and compared by 1-way ANOVA and Newman-Keuls post hoc test $(A, B)$, Student's $t$ test $(C, D)$, and $\chi^{2}$ test $(P<0.05$ from the expected distribution; $E)$. ** $P<$ $0.001, * * * P<0.0001$.

but not in the ipsilateral (left paw, LP) ischemic side (Fig. $8 D$ ), indicating a functional deficit due to ischemia. However, $S T I 1^{-/+}$mice showed decreased dexterity in their RP compared to wild-type controls to remove the tape (Fig. $8 E$ ). These experiments indicate that decreased STI1 levels affect brain injury after ischemic stroke, survival of animals, and their functional recovery.

To establish potential mechanisms by which STI1 may affect neuronal function after stroke, we examined the response of astrocytes and neuronal cultures to OGD. We found that intracellular STI1 was reduced in $S T I 1^{+/+}$astrocytes after OGD (Fig. 9A). In $S T I 1^{-/+}$ astrocytes, the intracellular levels of STI1 were further reduced by OGD. Experiments using proteasome in- hibitors indicated that reduced levels of STI1 were not due to increased protein degradation (not shown), suggesting the possibility of changes in secretion. Indeed, wild-type astrocytes increased STI1 secretion by close to 3-fold after OGD (Fig. 9B). Although astrocytes derived from $S T I 1^{-/+}$mice also showed increased secretion of STI1 following OGD, the levels of extracellular STI1 were, as expected, $\sim 2$-fold lower than those of wild-type astrocytes (Fig. $9 B$ ). Therefore, as a consequence of ischemia, astrocytes secrete significant amounts of STI1, (Fig. 9A, B); however, since $S T I 1^{-/+}$ astrocytes have $50 \%$ less protein, the amount of STI1 secreted by these mutated cells is lower. OGD did not increase cell death of astrocytes from either genotype (Fig. 9C).
A
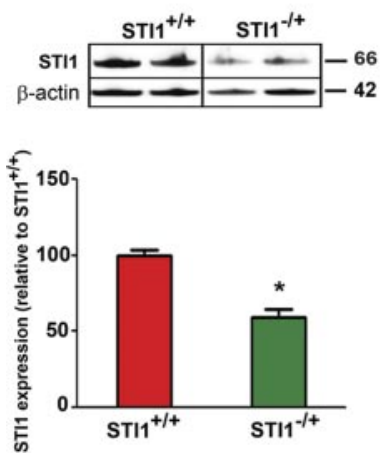

B
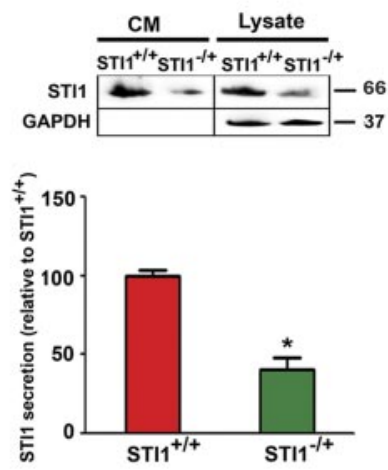

C
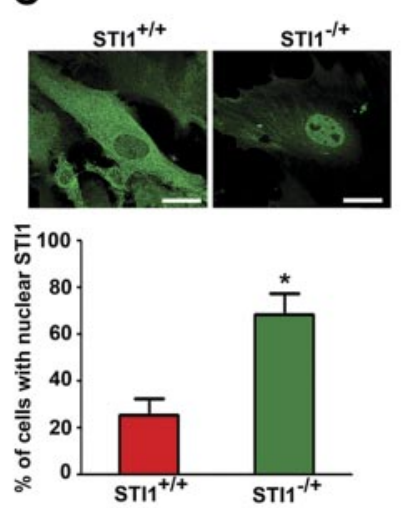

D
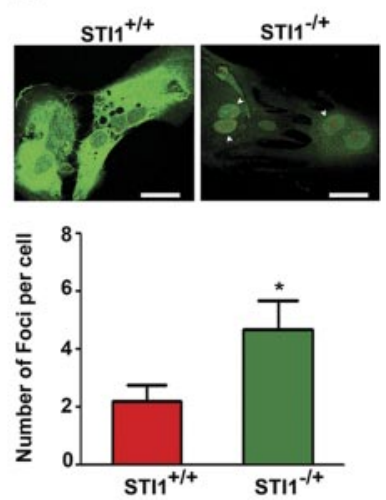

Figure 7. STI1 secretion, expression, and cellular localization in $S T I 1^{+/+}$and $S T I 1^{-/+}$astrocyte cultures. A) STI1 expression in $S T I 1^{+/+}$and $S T I 1^{-/+}$astrocytes (cultures obtained from 4 embryos/genotype). B) Detection of STI1 in CM from astrocytes (cultures obtained from 5 embryos/genotype). C) Immunofluorescence showing a reduction of STI1 labeling and localization of STI1 in $S T I 1^{+/+}$and $S T I 1^{-/+}$astrocytes (top panel) and quantification of cells with nuclear STI1 (bottom panel). Scale bars $=$ $15 \mu \mathrm{m} . D$ ) Top panel: immunofluorescence for STI1 expression (green) and labeling of $\gamma$-H2AX (red) in $S T I 1^{+/+}$and $S T I 1^{-/+}$ astrocytes. Scale bars $=30 \mu \mathrm{m}$. Bottom panel: quantification of number of foci per cell (cultures obtained from 7 embryos/genotype). Results are presented as means \pm SE. $* P<0.01$; Student's $t$ test. 

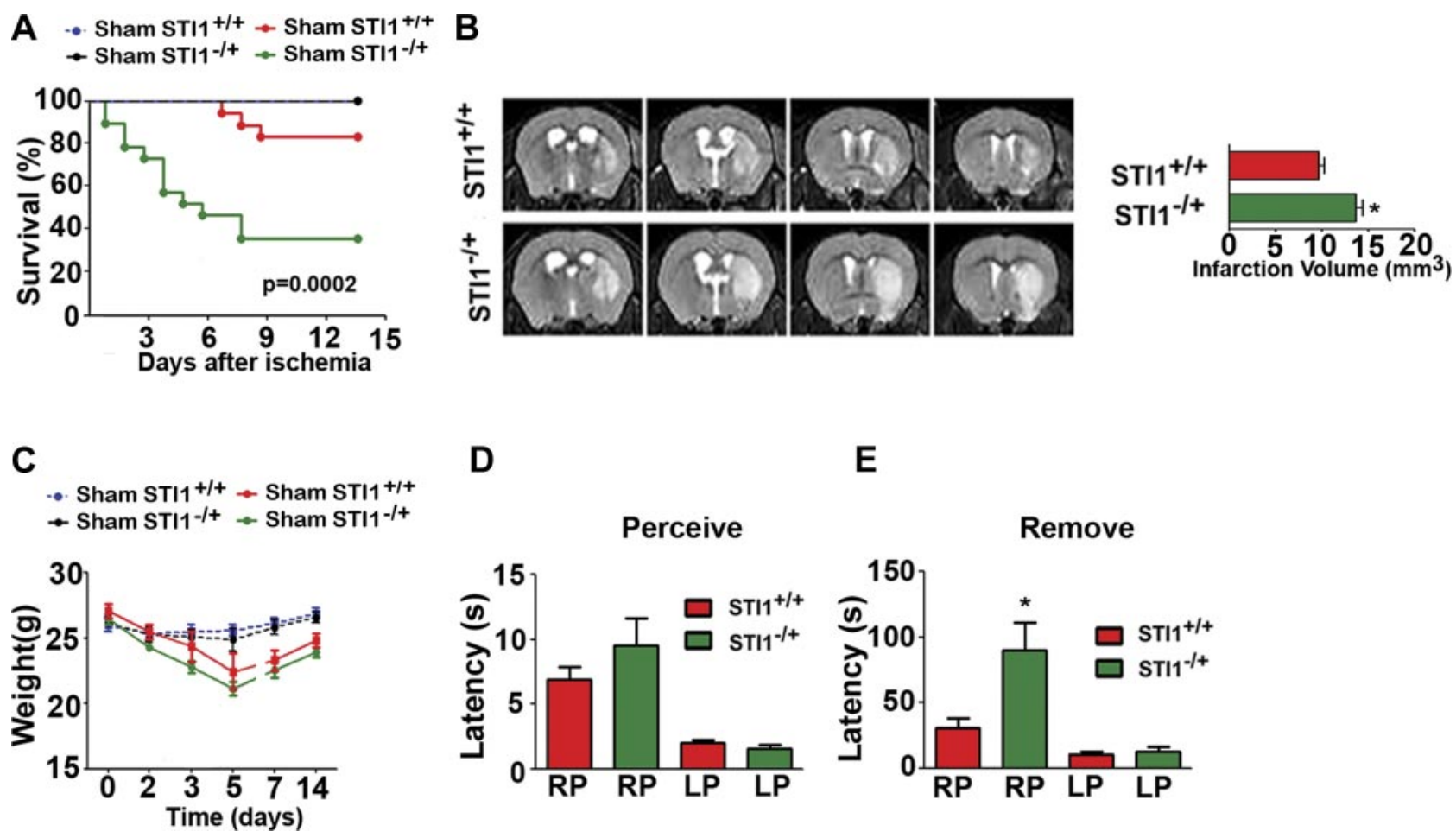

E

Figure 8. Regulation of functional recovery in ischemia by STI1. A) Survival curve of $S T I 1^{+/+}$and $S T I 1^{-/+}$mice submitted to 60 min of unilateral ischemia (MCAO). B) Representative MR images and group analyses of infarct volume in brains of $S T I 1^{+/+}$ $(n=6)$ and $S T I 1^{-/+}$mice $(n=5)$. C) Weight of mice submitted to MCAO $\left(n=6\right.$ Sham $S T I 1^{+/+}, n=5$ Sham $S T I 1^{-/+}, n=9$ $\left.S T I 1^{+/+}, n=7 S T I 1^{-/+}\right)$. D) Functional recovery of $S T I 1^{+/+}$and $S T I 1^{-/+}$mice submitted to MCAO, determined at d 7 after stroke using the tape removal test. Time to perceive the tape in the right paw (RP) or left paw (LP) $\left(n=9 S T I 1^{+/+}, n=7\right.$ $\left.S T I 1^{-/+}\right)$. E) Identical to $D$, but showing the time to remove the tape. Results are presented as means \pm SE; data were analyzed and compared by 1-way ANOVA and Newman-Keuls post hoc test, Student's $t$ test, and Mantel-Cox log-rank test $(P=0.0002 ; A)$. $* P<0.01$ vs. control mice.

In cultured primary neurons, $1 \mathrm{~h}$ OGD caused increased cell death (Fig. 9D), an effect that was similar in both control and $S T I 1^{-/+}$neurons. Hence, changes in intracellular levels of STI1 did not seem to affect the survival of neurons. To mimic the secretion of STI1 from astrocytes, we treated neurons with recombinant STI1, which reproduces the effects of astrocyte-secreted protein (40). Treatment of neurons from both genotypes with extracellular recombinant STI1 attenuated neuronal death in response to OGD (Fig. 9D), suggest- ing that rather than intracellular STI1, it is the extracellular protein that protects neurons from ischemic injury.

$\mathrm{PrP}^{\mathrm{C}}$, an STI1-interacting protein, plays a role in ischemic injury and increased levels of $\operatorname{PrP}^{\mathrm{C}}$ seem to protect, whereas lack of $\operatorname{PrP}^{\mathrm{C}}$ exacerbates neuronal injury in response to ischemic insults in vivo (41-43). To investigate the possibility that extracellular STI1 protects neurons via a $\operatorname{PrP}^{\mathrm{C}}$-dependent pathway in neurons, we repeated these experiments using neurons

TABLE 2. Physiological measurements before and during MCAO

\begin{tabular}{lll}
\hline \hline Measurement & \multicolumn{1}{c}{$S T I 1^{+/+}$} & \multicolumn{1}{c}{$S T I 1^{-/+}$} \\
\hline Before MCAO & & \\
$\quad$ Heart rate (beats/min) & $697.4 \pm 43.8(n=9)$ & $669.2 \pm 34.8(n=9)$ \\
$\quad$ Arterial blood pH & $7.193 \pm 0.003(n=3)$ & $7.233 \pm 0.007(n=3)$ \\
Oxygen saturation $(\%)$ & $99.37 \pm 3.74(n=3)$ & $97.80 \pm 5.8(n=3)$ \\
Temperature $\left({ }^{\circ} \mathrm{C}\right)$ & $35.90 \pm 0.30(n=3)$ & $36.20 \pm 0.36(n=3)$ \\
$\quad$ Glucose $(\mathrm{mM})$ & $8.067 \pm 0.633(n=3)$ & $8.833 \pm 0.033(n=3)$ \\
During MCAO & & \\
Heart rate $(\mathrm{beats} / \mathrm{min})$ & $693.1 \pm 42.9(n=6)$ & $693.1 \pm 55.9(n=4)$ \\
Arterial blood pH & $7.107 \pm 0.0201(n=6)$ & $7.100 \pm 0.044(n=4)$ \\
$\quad$ Oxygen saturation $(\%)$ & $99.32 \pm 3.47(n=6)$ & $73.55 \pm 10.31(n=4)$ \\
Temperature $\left({ }^{\circ} \mathrm{C}\right)$ & $34.35 \pm 0.43(n=6)$ & $34.65 \pm 0.52(n=4)$ \\
Glucose $(\mathrm{mM})$ & $10.03 \pm 1.73(n=6)$ & $9.650 \pm 1.707(n=4)$ \\
\hline
\end{tabular}

Values are expressed as means $\pm \mathrm{SE} . \mathrm{MCAO}$, middle cerebral artery occlusion. 

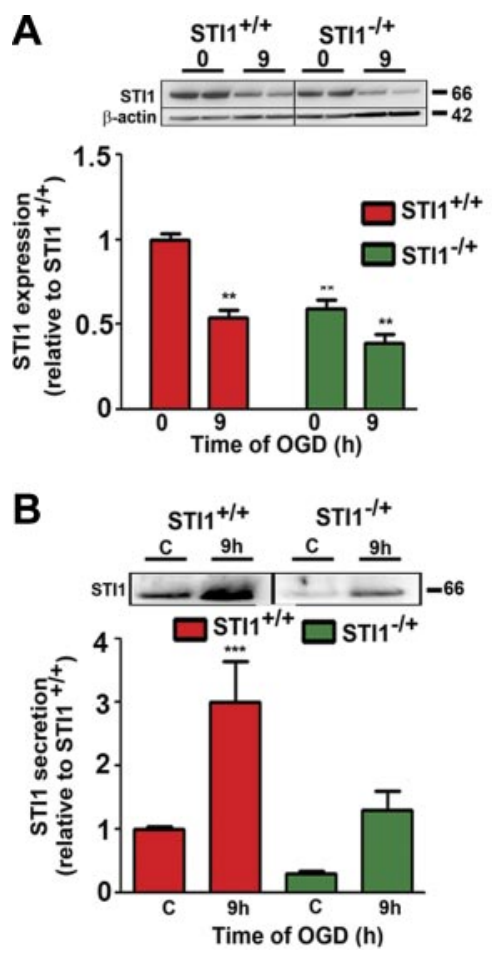

C

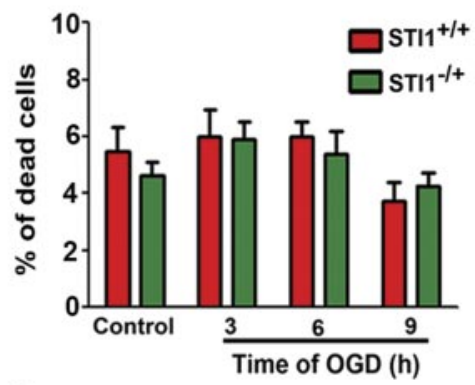

D

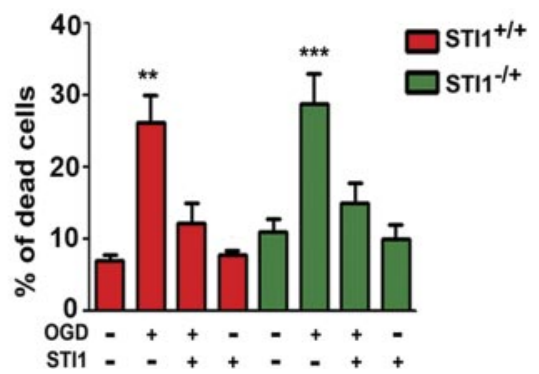

E

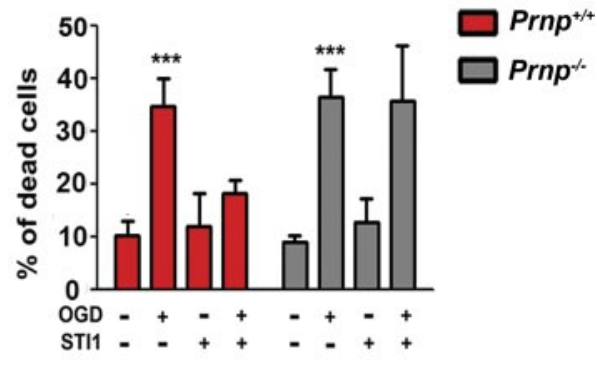

Figure 9. STI1 rescues neurons from OGD-induced cell death. A) Intracellular STI1 in astrocytes obtained from protein extracts after 0 or $9 \mathrm{~h}$ of OGD (protein extract from independent cultures from 6 embryos/genotype). $* * P<0.001$ vs. $0 \mathrm{~h}$ of OGD in wild-type mice. $B$ ) STI1 secretion from astrocytes in response to $9 \mathrm{~h}$ OGD (CM from independent cultures from 6 embryos/genotype). $* * * P<$ 0.0001 ws. all other conditions. C) Cell death in astrocytes exposed to OGD for 3 , 6 , and $9 \mathrm{~h}$ (independent cultures obtained from 5 embryos/genotype). D) Cell death induced by $1 \mathrm{~h}$ OGD in $S T I 1^{+/+}$and $S T I 1^{-/+}$neurons treated or not with
recombinant STI1 $(1 \mu \mathrm{M}) 1 \mathrm{~h}$ prior to OGD (independent cultures obtained from 6 embryos/genotype). $* * P<0.001, * * * P<$ 0.0001 vs. STI1 treatment or neurons without OGD. E) Cell death induced by $1 \mathrm{~h}$ OGD in wild-type and Prnp ${ }^{O / O}$ neurons treated or not with recombinant STI1 $(1 \mu \mathrm{M}) 1 \mathrm{~h}$ prior to OGD (independent cultures obtained from 4 embryos/ genotype). Results are presented as means \pm sE; data were analyzed and compared by 1-way ANOVA and Newman-Keuls post hoc test. $* * * P<0.0001$ vs. neurons without OGD treatment or wild-type neurons treated with STI1 after OGD.

of $\operatorname{PrP}^{\mathrm{C}}$-null mice $\left(\operatorname{Prn}^{0 / 0}\right)$. The neuroprotective effect of $\mathrm{STI} 1$ was prevented in neurons from $\operatorname{PrP}^{\mathrm{C}}$-null mice (Fig. 9E), suggesting that activation of $\operatorname{PrP}^{\mathrm{C}}$ by STI1 plays a role in protecting neurons against ischemic insult.

\section{DISCUSSION}

The present experiments demonstrate that Stip1 shows characteristics of a maternal (oogenetic)-effect gene, playing critical roles during development in mammals. $S T I 1^{-}{ }^{-}$blastocysts obtained from $S T I 1^{+/-}$intercrosses were observed at $50 \%$ of the expected mendelian frequency, suggesting that blastocysts originating from zygotes lacking sufficient maternally inherited STI1 may not survive. Interestingly, surviving $S T I 1^{-/-}$ blastocysts showed immunostaining for STI1, suggesting the possibility that part of the blastocyts may have received sufficient maternally inherited STI1 to allow development of embryos. It would be of interest to define the precise mechanism by which maternally derived STI1 is transferred to blastocysts. Embryonically expressed STI1 is critical in later stages of development, as mutant embryos could not survive past E10.5. We show that maternal STI1 protein might be transferred to embryos in later stages of development, as we could detect small amounts of STI1 immunoreactivity in E10.5 embryos, likely due to placental disruption. Notably, we did not detect STI1 mRNA in $S T I 1^{-{ }^{-}}$E10.5 embryos, indicating lack of embryonic STI1 protein synthesis. The rescue of lethality by transgenic BAC expression supports the notion that STI1 has unique roles during development and that maternally transferred STI1 cannot support embryonic development. Embryonic lethality is commonly associated with placental dysfunction in the E9-E12 stage. Interestingly, Hsp90ß-knockout mice (44), but not Hsp90 $\alpha$-knockout mice (45), present disrupted placenta. Hence, placental disruption may also contribute to embryonic lethality in STI1 mutant embryos.

Despite recent insights from structural models of STI1 interaction with Hsp70 and Hsp90 demonstrating STI1 regulation of client recruitment $(7,46-48)$, it is unknown whether STI1 has unique or overlapping roles in mammals in vivo. Our data suggest that loss of embryonic STI1 is not tolerated during development, and cells present decreased resilience to stress, showing increased DNA damage and cell death. Hence, other cochaperones do not seem to be able to compensate for the loss of STI1. These results contrast with those of mice deficient for p23, another Hsp90 chaperone, which present perinatal lethality specifically related to skin and lung development (49), suggesting distinct requirements for different cochaperones during development.

The early effects of STI1 in embryogenesis are compatible with its regulation of stem cell self-renewal (50). Interestingly, Hsp90 and, more recently, STI1 have 
been shown to regulate epigenetic programs and transposon silencing via piRNAs in Drosophila $(8,51)$. Remarkably, maternal STI1 appears to influence canalization in Drosophila via the Piwi pathway (8). Future studies aimed at further defining these mechanisms may provide novel insight in mammalian embryonic development.

We show that STI1 has a critical role in cellular survival. This conclusion is supported by the increased cell death in embryos and the inability to maintain $S T I 1^{-/-}$MEFs in culture. Because of the early death that we observed in blastocysts, as well as the inability of mutant cells to survive, we favor the possibility that the placental defect that we identified contributes to, but it is not the only cause of, cellular death in these mutant embryos. These effects of Stip1 seem to depend, at least in part, on intracellular STI1, as we were unable to rescue $S T I 1^{-/-}$MEFs using recombinant extracellular STI1, but could rescue $S T I 1^{-/-}$mice by transgenic expression of a BAC containing Stip1. The increase in foci number in $S T I 1^{-/-}$MEFs indicates that lack of chaperone activity may affect DNA damage response. Interestingly, Hsp90, which is regulated by STI1, has been previously implicated in the DNA damage response (52-55). By targeting STI1, we likely affected the functions of a wide range of Hsp90/Hsp70 client proteins (56-58). Indeed, this seems to be the case, given that three known Hsp90 clients (59-61) show reduced levels in STI1-mutant mice, even though Hsp90 levels were unaffected. In contrast with Hsp90 and Hsp70 that have different isoforms, there are no known homologs for Stip1, which may explain why we observed such striking phenotype during development. Given the very large number of Hsp90 client proteins $(5,56,57)$, it is unlikely that the phenotypes that we uncovered are related to one specific client. It is also unclear whether the remaining amounts of Hsp90 client proteins in STI1 mutant embryos are functional. Hence, inhibitors of STI1 may have more widespread effects in mammals than inhibitors of Hsp90. Indeed, a recent report demonstrates that inhibition of STI1 interaction with Hsp90 by drugs is effective to kill cancer cells (62).

Our experiment using a stroke model supports an important role for endogenous STI1 in the recovery from ischemic injury in vivo. $\operatorname{PrP}^{\mathrm{C}}$ expression has been shown to protect the brain following ischemic insults, and lack of $\operatorname{PrP}^{\mathrm{C}}$ leads to an increase in neuronal injury in stroke models $(41,42,63)$. However, the exact mechanisms by which $\operatorname{PrP}^{\mathrm{C}}$ influences outcomes in stroke are unknown. We now show that OGD, used as an in vitro model of ischemic insult, can increase secretion of STI1 from astrocytes and that secretion from $S T I 1^{-/+}$astrocytes is decreased in this condition. Our experiments using cultured neurons suggest that the increased sensitivity observed in vivo in $S T I 1^{-/+}$ mice may not be related to decreased intracellular levels of STI1 in neurons, as both control and $S T I 1^{-/+}$ neurons responded similarly to OGD. In these neuronal cultures, extracellular STI1 was able to provide neuroprotection for OGD-induced neuronal death. Moreover, this effect of STI1 was strictly dependent on the presence of $\operatorname{PrP}^{\mathrm{C}}$ in neurons. These results expand previous observations in which STI1 was shown to prevent neuronal death induced by staurosporine (14, 17) to demonstrate a role for this secreted cochaperone in a pathological relevant insult, ischemic injury. Our in vitro data with recombinant STI1 and in vivo with $S T I 1^{-/+}$mice suggest that lack of STI1-mediated signaling may underlie the increased sensitivity of $\operatorname{PrP}^{\mathrm{C}}$ null mice to ischemic injury.

Our experiments provide novel evidence that STI1 plays a unique and nonoverlapping role as a cochaperone during embryonic development and in cellular survival, suggesting that loss of STI1-regulated chaperone activity is not tolerated. Our data also support a role for STI1 in neuroprotection against ischemic insult, by a mechanism involving increased secretion from astrocytes and activation of $\operatorname{PrP}^{\mathrm{C}}$. Hence, STI1 is a stress-response protein that presents multiple intracellular and extracellular roles with unique properties for protection of cells against stress.

The authors thank Joy Dunmore-Buyze for micro-CT sample preparation and image acquisition and Sanda Raulic and Weiyan Wen for help with mouse colonies. The authors also thank Dr. Gerald Kidder (University of Western Ontario) for help with data analysis and interpretation. This work was supported by grants from the Canadian Institute of Health Research (MOP 93651 and MOP 126000, M.A.M.P., R.B., and V.F.P), PrioNet-Canada (M.A.M.P., R.B. and V.F.P.), Canadian Foundation for Innovation (M.A.M.P., V.F.P., and R.G.), Ontario Research Fund (M.A.M.P., V.F.P., and R.G.), the Alzheimer's Association (M.A.M.P., V.R.M., and V.F.P.), Conselho Nacional de Desenvolvimento Científico e Tecnológico (CNPq; Brazil; V.R.M.), and Fundação de Amparo à Pesquisa do Estado de São Paulo (FAPESP; São Paulo, Brazil; V.R.M.). F.H.B. and I.N.S. received fellowships from the Department of Foreign Affairs and International Trade (Canada). I.N.S. and D.F.G. received a fellowship from Coordenação de Aperfeiçoamento de Pessoal de Nível Superior (Brazil). A.H.M. received a fellowship from the Ontario Graduate Scholarship Program; T.G.S. and M.R. received a fellowship from FAPESP; A.L.G. received a fellowship from CNPq. R.G. and M.D. are supported by awards from the Heart and Stroke Foundation of Canada.

\section{REFERENCES}

1. Picard, D. (2002) Heat-shock protein 90, a chaperone for folding and regulation. Cell. Mol. Life Sci. 59, 1640-1648

2. Young, J. C., Agashe, V. R., Siegers, K., and Hartl, F. U. (2004) Pathways of chaperone-mediated protein folding in the cytosol. Nat. Rev. Mol. Cell Biol. 5, 781-791

3. Pearl, L. H., and Prodromou, C. (2006) Structure and mechanism of the Hsp90 molecular chaperone machinery. Annu. Rev. Biochem. 75, 271-294

4. Linden, R., Martins, V. R., Prado, M. A., Cammarota, M., Izquierdo, I., and Brentani, R. R. (2008) Physiology of the prion protein. Physiol. Rev. 88, 673-728

5. Taipale, M., Jarosz, D. F., and Lindquist, S. (2010) HSP90 at the hub of protein homeostasis: emerging mechanistic insights. Nat. Rev. Mol. Cell Biol. 11, 515-528

6. Richter, K., Muschler, P., Hainzl, O., Reinstein, J., and Buchner, J. (2003) Stil is a non-competitive inhibitor of the Hsp90 
ATPase. Binding prevents the N-terminal dimerization reaction during the atpase cycle. J. Biol. Chem. 278, 10328-10333

7. Southworth, D. R., and Agard, D. A. (2011) Client-loading conformation of the Hsp90 molecular chaperone revealed in the cryo-EM structure of the human Hsp90: Hop complex. Mol. Cell 42, 771-781

8. Gangaraju, V. K., Yin, H., Weiner, M. M., Wang, J., Huang, X. A., and Lin, H. (2011) Drosophila Piwi functions in Hsp90-mediated suppression of phenotypic variation. Nat. Genet. 43, 153-158

9. Eustace, B. K., Sakurai, T., Stewart, J. K., Yimlamai, D., Unger, C., Zehetmeier, C., Lain, B., Torella, C., Henning, S. W., Beste, G., Scroggins, B. T., Neckers, L., Ilag, L. L., and Jay, D. G. (2004) Functional proteomic screens reveal an essential extracellular role for Hsp90 alpha in cancer cell invasiveness. Nat. Cell Biol. 6, 507-514

10. De Maio, A. (2011) Extracellular heat shock proteins, cellular export vesicles, and the stress observation system: a form of communication during injury, infection, and cell damage. Cell Stress Chaperones 16, 235-249

11. Lima, F. R., Arantes, C. P., Muras, A. G., Nomizo, R., Brentani, R. R., and Martins, V. R. (2007) Cellular prion protein expression in astrocytes modulates neuronal survival and differentiation. J. Neurochem. 103, 2164-2176

12. Arantes, C., Nomizo, R., Lopes, M. H., Hajj, G. N., Lima, F. R., and Martins, V. R. (2009) Prion protein and its ligand stress inducible protein 1 regulate astrocyte development. Glia $\mathbf{5 7}$, $1439-1449$

13. Hajj, G. N., Arantes, C. P., Dias, M. V., Roffe, M., Costa-Silva, B., Lopes, M. H., Porto-Carreiro, I., Rabachini, T., Lima, F. R., Beraldo, F. H., Prado, M. A. M., Linden, R., and Martins, V. R. (2013) The unconventional secretion of stress-inducible protein 1 by a heterogeneous population of extracellular vesicles. [Epub ahead of print] Cell. Mol. Life Sci. 10.1007/s00018-0131328-y

14. Beraldo, F. H., Arantes, C. P., Santos, T. G., Queiroz, N. G., Young, K., Rylett, R. J., Markus, R. P., Prado, M. A., and Martins, V. R. (2010) Role of alpha7 nicotinic acetylcholine receptor in calcium signaling induced by prion protein interaction with stress-inducible protein 1. J. Biol. Chem. 285, 36542-36550

15. Santos, T. G., Beraldo, F. H., Hajj, G. N., Lopes, M. H., Roffe, M., Lupinacci, F. C., Ostapchenko, V. G., Prado, V. F., Prado, M. A., and Martins, V. R. (2013) Laminin-gammal chain and stress inducible protein 1 synergistically mediate PrPC-dependent axonal growth via $\mathrm{Ca}^{2+}$ mobilization in dorsal root ganglia neurons. J. Neurochem. 124, 210-223

16. Beraldo, F. H., Arantes, C. P., Santos, T. G., Queiroz, N. G., Young, K., Rylett, R. J., Markus, R. P., Prado, M. A., and Martins, V. R. (2010) Role of $\alpha 7$ nicotinic acetylcholine receptor in calcium signaling induced by prion protein interaction with stress-inducible protein 1. J. Biol. Chem. 19, 36542-36550

17. Lopes, M. H., Hajj, G. N., Muras, A. G., Mancini, G. L., Castro, R. M., Ribeiro, K. C., Brentani, R. R., Linden, R., and Martins, V. R. (2005) Interaction of cellular prion and stress-inducible protein 1 promotes neuritogenesis and neuroprotection by distinct signaling pathways. J. Neurosci. 7, 11330-11339

18. Chang, H. C., Nathan, D. F., and Lindquist, S. (1997) In vivo analysis of the Hsp90 cochaperone Stil (p60). Mol. Cell. Biol. 17, $318-325$

19. Song, H. O., Lee, W., An, K., Lee, H. S., Cho, J. H., Park, Z. Y., and Ahnn, J. (2009) C. elegans STI-1, the homolog of Stil/Hop, is involved in aging and stress response. J. Mol. Biol. 390, 604-617

20. Prado, V. F., Martins-Silva, C., de Castro, B. M., Lima, R. F., Barros, D. M., Amaral, E., Ramsey, A. J., Sotnikova, T. D., Ramirez, M. R., Kim, H. G., Rossato, J. I., Koenen, J., Quan, H., Cota, V. R., Moraes, M. F., Gomez, M. V., Guatimosim, C., Wetsel, W. C., Kushmerick, C., Pereira, G. S., Gainetdinov, R. R., Izquierdo, I., Caron, M. G., and Prado, M. A. (2006) Mice deficient for the vesicular acetylcholine transporter are myasthenic and have deficits in object and social recognition. Neuron 51, 601-612

21. Martins-Silva, C., De Jaeger, X, Guzman, M. S., Lima, R. D., Santos, M. S., Kushmerick, C., Gomez, M. V., Caron, M. G., Prado, M. A., and Prado, V. F. (2011) Novel strains of mice deficient for the vesicular acetylcholine transporter: insights on transcriptional regulation and control of locomotor behavior. PLOS ONE 6, e17611
22. Guzman, M. S., De, J., X, Raulic, S., Souza, I. A., Li, A. X., Schmid, S., Menon, R. S., Gainetdinov, R. R., Caron, M. G., Bartha, R., Prado, V. F., and Prado, M. A. (2011) Elimination of the vesicular acetylcholine transporter in the striatum reveals regulation of behaviour by cholinergic-glutamatergic co-transmission. PLoS Biol. 9, e1001194

23. Migliorini, D., Lazzerini, D. E., Danovi, D., Jochemsen, A., Capillo, M., Gobbi, A., Helin, K., Pelicci, P. G., and Marine, J. C. (2002) Mdm4 (Mdmx) regulates p53-induced growth arrest and neuronal cell death during early embryonic mouse development. Mol. Cell. Biol. 22, 5527-5538

24. Degenhardt, K., Wright, A. C., Horng, D., Padmanabhan, A., and Epstein, J. A. (2010) Rapid 3D phenotyping of cardiovascular development in mouse embryos by micro-CT with iodine staining. Circ. Cardiovasc. Imaging 3, 314-322

25. Badea, C. T., Drangova, M., Holdsworth, D. W., and Johnson, G. A. (2008) In vivo small-animal imaging using micro-CT and digital subtraction angiography. Phys. Med. Biol. 53, R319-R350

26. Longa, E. Z., Weinstein, P. R., Carlson, S., and Cummins, R. (1989) Reversible middle cerebral artery occlusion without craniectomy in rats. Stroke 20, 84-91

27. Bederson, J. B., Pitts, L. H., Tsuji, M., Nishimura, M. C., Davis, R. L., and Bartkowski, H. (1986) Rat middle cerebral artery occlusion: evaluation of the model and development of a neurologic examination. Stroke 17, 472-476

28. Bouet, V., Boulouard, M., Toutain, J., Divoux, D., Bernaudin, M., Schumann-Bard, P., and Freret, T. (2009) The adhesive removal test: a sensitive method to assess sensorimotor deficits in mice. Nat. Protoc. 4, 1560-1564

29. Erlich, R. B., Kahn, S. A., Lima, F. R., Muras, A. G., Martins, R. A., Linden, R., Chiarini, L. B., Martins, V. R., and Moura, N., V (2007) STI1 promotes glioma proliferation through MAPK and PI3K pathways. Glia 55, 1690-1698

30. Tsai, C. L., Tsai, C. N., Lin, C. Y., Chen, H. W., Lee, Y. S., Chao, A., Wang, T. H., Wang, H. S., and Lai, C. H. (2012) Secreted stress-induced phosphoprotein 1 activates the ALK2-SMAD signaling pathways and promotes cell proliferation of ovarian cancer cells. Cell Rep. 2, 283-293

31. Wang, T. H., Chao, A., Tsai, C. L., Chang, C. L., Chen, S. H., Lee, Y. S., Chen, J. K., Lin, Y. J., Chang, P. Y., Wang, C. J., Chao, A. S., Chang, S. D., Chang, T. C., Lai, C. H., and Wang, H. S. (2010) Stress-induced phosphoprotein 1 as a secreted biomarker for human ovarian cancer promotes cancer cell proliferation. Mol. Cell. Proteomics 9, 1873-1884

32. Nicolet, C. M., and Craig, E. A. (1989) Isolation and characterization of STI1, a stress-inducible gene from Saccharomyces cerevisiae. Mol. Cell. Biol. 9, 3638-3646

33. Matkovich, S. J., Diwan, A., Klanke, J. L., Hammer, D. J., Marreez, Y., Odley, A. M., Brunskill, E. W., Koch, W. J., Schwartz, R. J., and Dorn, G. W. (2006) Cardiac-specific ablation of G-protein receptor kinase 2 redefines its roles in heart development and beta-adrenergic signaling. Circ. Res. 99, 996-1003

34. Takeda, K., Noguchi, K., Shi, W., Tanaka, T., Matsumoto, M., Yoshida, N., Kishimoto, T., and Akira, S. (1997) Targeted disruption of the mouse Stat3 gene leads to early embryonic lethality. Proc. Natl. Acad. Sci. U. S. A. 94, 3801-3804

35. Donehower, L. A., Harvey, M., Slagle, B. L., McArthur, M. J., Montgomery, C. A., Jr., Butel, J. S., and Bradley, A. (1992) Mice deficient for p53 are developmentally normal but susceptible to spontaneous tumours. Nature 356, 215-221

36. Lukas, J., Lukas, C., and Bartek, J. (2011) More than just a focus: The chromatin response to DNA damage and its role in genome integrity maintenance. Nat. Cell Biol. 13, 1161-1169

37. Bartek, J., Bartkova, J., and Lukas, J. (2007) DNA damage signalling guards against activated oncogenes and tumour progression. Oncogene 26, 7773-7779

38. Daniel, S., Bradley, G., Longshaw, V. M., Söti, C., Csermely, P., and Blatch, G. L. (2008) Nuclear translocation of the phosphoprotein Hop (Hsp70/Hsp90 organizing protein) occurs under heat shock, and its proposed nuclear localization signal is involved in Hsp90 binding. Biochim. Biophys. Acta 1783, 10031014

39. Longshaw, V. M., Chapple, J. P., Balda, M. S., Cheetham, M. E., and Blatch, G. L. (2004) Nuclear translocation of the Hsp70/ Hsp90 organizing protein $\mathrm{mSTI1}$ is regulated by cell cycle kinases. J. Cell Sci. 15, 701-710 
40. Caetano, F. A., Lopes, M. H., Hajj, G. N., Machado, C. F., Pinto, A. C., Magalhaes, A. C., Vieira, M. P., Americo, T. A., Massensini, A. R., Priola, S. A., Vorberg, I., Gomez, M. V., Linden, R., Prado, V. F., Martins, V. R., and Prado, M. A. (2008) Endocytosis of prion protein is required for ERK1/2 signaling induced by stress-inducible protein 1. J. Neurosci. 28, 6691-6702

41. McLennan, N. F., Brennan, P. M., McNeill, A., Davies, I., Fotheringham, A., Rennison, K. A., Ritchie, D., Brannan, F., Head, M. W., Ironside, J. W., Williams, A., and Bell, J. E. (2004) Prion protein accumulation and neuroprotection in hypoxic brain damage. Am. J. Pathol. 165, 227-235

42. Shyu, W. C., Lin, S. Z., Chiang, M. F., Ding, D. C., Li, K. W., Chen, S. F., Yang, H. I., and Li, H. (2005) Overexpression of PrPC by adenovirus-mediated gene targeting reduces ischemic injury in a stroke rat model. J. Neurosci. 25, 8967-8977

43. Guillot-Sestier, M. V., Sunyach, C., Druon, C., Scarzello, S., and Checler, F. (2009) The alpha-secretase-derived N-terminal product of cellular prion, N1 displays neuroprotective function, in vitro and in vivo. J. Biol. Chem. 284, 35973-35986

44. Voss, A. K., Thomas, T., and Gruss, P. (2000) Mice lacking HSP90 $\beta$ fail to develop a placental labyrinth. Development 127, $1-11$

45. Imai, T., Kato, Y., Kajiwara, C., Mizukami, S., Ishige, I., Ichiyanagi, T., Hikida, M., Wang, J. Y., and Udono, H. (2011) Heat shock protein 90 (HSP90) contributes to cytosolic translocation of extracellular antigen for cross-presentation by dendritic cells. Proc. Natl. Acad. Sci. U. S. A. 108, 16363-16368

46. Lee, C. T., Graf, C., Mayer, F. J., Richter, S. M., and Mayer, M. P. (2012) Dynamics of the regulation of Hsp90 by the co-chaperone Stil. EMBO. J. 31, 1518-1528

47. Schmid, A. B., Lagleder, S., Grawert, M. A., Rohl, A., Hagn, F., Wandinger, S. K., Cox, M. B., Demmer, O., Richter, K., Groll, M., Kessler, H., and Buchner, J. (2012) The architecture of functional modules in the Hsp90 co-chaperone Stil/Hop. EMBO J. 31, 1506-1517

48. Scheufler, C., Brinker, A., Bourenkov, G., Pegoraro, S., Moroder, L., Bartunik, H., Hartl, F. U., and Moarefi, I. (2000) Structure of TPR domain-peptide complexes: critical elements in the assembly of the Hsp70-Hsp90 multichaperone machine. Cell 101, 199-210

49. Grad, I., McKee, T. A., Ludwig, S. M., Hoyle, G. W., Ruiz, P., Wurst, W., Floss, T., Miller, C. A., III, and Picard, D. (2006) The Hsp90 cochaperone p23 is essential for perinatal survival. Mol. Cell. Biol. 26, 8976-8983

50. Santos, T. G., Silva, I. R., Costa-Silva, B., Lepique, A. P., Martins, V. R., and Lopes, M. H. (2011) Enhanced neural progenitor/ stem cells self-renewal via the interaction of stress-inducible protein 1 with the prion protein. Stem Cells 29, 1126-1136

51. Specchia, V., Piacentini, L., Tritto, P., Fanti, L., D’Alessandro, R., Palumbo, G., Pimpinelli, S., and Bozzetti, M. P. (2010) Hsp90 prevents phenotypic variation by suppressing the mutagenic activity of transposons. Nature 463, 662-665
52. Arlander, S. J., Eapen, A. K., Vroman, B. T., McDonald, R. J., Toft, D. O., and Karnitz, L. M. (2003) Hsp90 inhibition depletes Chk1 and sensitizes tumor cells to replication stress. J. Biol. Chem. 278, 52572-52577

53. Oda, T., Hayano, T., Miyaso, H., Takahashi, N., and Yamashita, T. (2007) Hsp90 regulates the Fanconi anemia DNA damage response pathway. Blood 109, 5016-5026

54. Ha, K., Fiskus, W., Rao, R., Balusu, R., Venkannagari, S., Nalabothula, N. R., and Bhalla, K. N. (2011) Hsp90 inhibitormediated disruption of chaperone association of ATR with hsp90 sensitizes cancer cells to DNA damage. Mol. Cancer Ther. 10, 1194-1206

55. Quanz, M., Herbette, A., Sayarath, M., de, K. L., Dubois, T., Sun, J. S., and Dutreix, M. (2012) Heat shock protein 90alpha (Hsp90alpha) is phosphorylated in response to DNA damage and accumulates in repair foci. J. Biol. Chem. 287, 8803-8815

56. Sharma, K., Vabulas, R. M., Macek, B., Pinkert, S., Cox, J., Mann, M., and Hartl, F. U. (2012) Quantitative proteomics reveals that Hsp90 inhibition preferentially targets kinases and the DNA damage response. Mol. Cell. Proteomics 11, M111

57. Zhao, R., Davey, M., Hsu, Y. C., Kaplanek, P., Tong, A., Parsons, A. B., Krogan, N., Cagney, G., Mai, D., Greenblatt, J., Boone, C., Emili, A., and Houry, W. A. (2005) Navigating the chaperone network: an integrative map of physical and genetic interactions mediated by the hsp90 chaperone. Cell 120, 715-727

58. Zhao, R., and Houry, W. A. (2007) Molecular interaction network of the Hsp90 chaperone system. Adv. Exp. Med. Biol. 594, 27-36

59. Shah, M., Patel, K., Fried, V. A., and Sehgal, P. B. (2002) Interactions of STAT3 with caveolin-1 and heat shock protein 90 in plasma membrane raft and cytosolic complexes. Preservation of cytokine signaling during fever. J. Biol. Chem. 277, 4566245669

60. Muller, L., Schaupp, A., Walerych, D., Wegele, H., and Buchner, J. (2004) Hsp90 regulates the activity of wild type p53 under physiological and elevated temperatures. J. Biol. Chem. 279, 48846-48854

61. Luo, J., and Benovic, J. L. (2003) G protein-coupled receptor kinase interaction with Hsp90 mediates kinase maturation. J. Biol. Chem. 278, 50908-50914

62. Pimienta, G., Herbert, K. M., and Regan, L. (2011) A compound that inhibits the HOP-Hsp90 complex formation and has unique killing effects in breast cancer cell lines. Mol. Pharm. 8, 2252-2261

63. Mitsios, N., Saka, M., Krupinski, J., Pennucci, R., Sanfeliu, C., Miguel, T. M., Gaffney, J., Kumar, P., Kumar, S., Sullivan, M., and Slevin, M. (2007) Cellular prion protein is increased in the plasma and peri-infarcted brain tissue after acute stroke. J. Neurosci. Res. 85, 602-611

Received for publication April 11, 2013. Accepted for publication May 14, 2013 